\title{
Organisational politics and strategies - a socialisation into a legitimacy whirlpool
}

\section{Mary Low* and Stephen Schollum}

\author{
School of Accounting, Finance and Economics, \\ Division of Management, \\ University of Waikato, \\ Hamilton, New Zealand \\ Email: mary.low@waikato.ac.nz \\ Email: stephenschollum@gmail.com \\ *Corresponding author
}

\begin{abstract}
Legitimacy is one of the oldest problems in the history of social thinking and yet this concept appears to have received little attention in accounting and business research literature to explain and enhance our understanding of why corporate debacles and accounting scandals continue unabated. The focus of this paper is to bring in a theoretical lens to explain that it is more possibly the types of legitimation strategies that occurs through a socialisation process within organisations and professional institutions that allow individuals to fulfil different types of ethical responsibilities for the organisations and institutions that they work within and for rather than exercising their ethical responsibilities to wider society. The paper is valuable as it appears that through a socialisation process, individuals adopt legitimation strategies that supposedly fulfils the 'social contract' between organisations and society but are actually questionable activities devoid of moral character which do not really benefit society as a whole.
\end{abstract}

Keywords: organisational politics and strategy; legitimacy theory; legitimation strategies; socialisation.

Reference to this paper should be made as follows: Low, M. and Schollum, S. (2021) 'Organisational politics and strategies - a socialisation into a legitimacy whirlpool', Int. J. Critical Accounting, Vol. 12, No. 1, pp.54-90.

Biographical notes: Mary Low is a Senior Lecturer at the University of Waikato. She holds a Master's in Management Studies in Accounting and Doctor of Philosophy at the UoW. She is a chartered accountant member of the Chartered Accountants Australia + New Zealand and Fellow CPA Australia member. Her research interests include financial reporting issues, corporate governance, ethical issues in accounting and accounting education.

Stephen Schollum received his $\mathrm{PhD}$ from the University of Auckland. He is currently a Teaching Fellow, and retired Senior Lecturer from the University of Waikato. His research interests are business regulation - accountability, compliance and disclosure, applied small business and commercial practices, government steering mechanisms for business and professions, real estate and professional reform initiatives.

This paper is a revised and expanded version of a paper entitled 'Strategy and character... if you have to be without one, then let it be strategy; that is legitimation strategies' presented at the International Conference on Critical Accounting, New York, USA, 28-29 April 2011. 


\section{Introduction}

Corporate and individual ethics gained new emphasis during the early 2000s because of corporate meltdowns (Underwood, 2004) and accounting scandals that while they imploded in many countries, for instance, the USA, the UK, Australia, France, the Netherlands and South Korea (see Young, 2003), worldwide implications were felt not just by corporate and accounting players but also society in general. More recently in New Zealand, there has been a string of finance and property investment company collapses that have left investors reeling while their millionaire directors remain drenched with wealth as portrayed by the media in the cases of Bridgecorp, Hanover Finance and the Blue Chip companies to name a few. For instance, "Hanover co-founder Mark Hotchin ... celebrated his 50th birthday, partying with more than 80 mates at one of Fiji's most exclusive resorts - angering investors who lost millions in the finance company" [Marshall, (2008), p.3]; not to be outdone by his co-founder, "Eric Watson ups the stakes with exclusive Istanbul party" to celebrate his 50th [McDonald, (2009), p.1]; "Bryers [Blue Chip founder] \$30m properties revealed" [Ninness, (2008), p.1] and Petricevic [former chief executive, director and major shareholder] spent up large while Bridegcorp burned (McNabb, 2008). How can this be so? What organisational politics and strategies did these executives and directors employ that enabled them to continue to enjoy the 'bubbles of life' while their investors both 'naïve' and others not so naïve, have lost most of their cash investments in these failed companies.

These corporate meltdowns also affect seemingly resilient companies in the international arena. The highly publicised Enron case, whose reputed systems and organisational strategies saw it named by Fortune magazine as USA's most innovative company six years in a row (Bryce, 2003) did not prevent its collapse. One view of Enron's dramatic demise is that the company represented the height of the excesses of socially irresponsible 'turbo-capitalism' and that Anderson's connivance in these excesses shows what happens when such practices are seen 'just as the way that the world works' (Grey, 2003). Another view is that Enron failed not so much because of faulty accounting or poor regulation; it was more so because this company's "key leaders lost their moral/ethical direction" [Bryce, (2003), p.11]. Clark and Lavelle (2006, p.44) states that the "very strategies and character traits that had made Lay and Skilling rich and powerful turned them into felons." What strategies and character traits were these and how did they produce such disastrous consequences for these former CEOs that they now "face prison sentences that could keep them behind bars for the rest of their lives" (ibid). How did these 'key leaders' get involved in organisation politics and strategies that resulted not only in their downfall but also the company's demise? Does organisational and professional socialisation play an important role in causing individuals to lose their moral compass? Was it subsequently a whirlpool of legitimacy strategies that finally imploded on these players and with its implosion, such disastrous consequences? It was a much publicised and well-known fact that Enron had in place a comprehensive state-of-the-art and award-winning management control and governance system and yet this sophisticated and comprehensive set of management controls failed to prevent and detect widespread and continued corporate-wide fraud, information manipulation and dishonesty (Free et al., 2007); the question remains begging, why? Craig and Amernic (2004, p.815) indicate "allegations of sham accounting, evidence shredding and undue political influence all emerged from the smouldering volcano of the failed Enron." 
It is widely believed that leadership creates the vital link between organisational effectiveness and employees' performance at an organisational level (Jing and Avery, 2008). Management research literature places significant emphasis on 'leadership' as a prominent factor that contributes to business excellence and success. Safferstone (2005) writes that "beginning in the early 1900s, many authors identified, discussed, and analyzed critical business issues and the consequences of these issues for leaders and their organizations" (p.38) but that "recent writers have concentrated on the leader's competencies and capabilities, and perhaps more importantly, the complex, reciprocal, interpersonal relationship that develops between leader and follower within the organizational context" (p.39). He also notes that "[G]iven large organizations' societal responsibilities and political and economic impact, there is an increasing emphasis on leaders' social, ethical, and moral responsibilities" [Safferstone, (2005), p.39]. General H. Norman Schwarzkopf who led coalition forces in Desert Storm quoted numerously in research publications on leadership and corporate management (Brymer, 2005; Eppler, 2005; Herrick, 2003) states: "Leadership is a potent combination of strategy and character. But if you must be without one, be without strategy." It could be argued that the corporate meltdowns and accounting scandals were not so much that the key leaders in these imploded organisations lacked 'strategy'. Undeniably, they had the types of organisational politics and strategies in place that aimed for personal wealth accumulation, success and rewards. More possibly, it was because they lacked the potent element from Schwarzkopf's leadership combination relating to 'character' (that is, moral character). The important message is that if ethics is to become an integral part of business conduct then appropriate ethical behaviour must be inherently knitted into the fabric of organisational life, and as a consequence, attention needs to focus on a philosophical analysis of the power and authority wielded by managers in organisations (Phillips, 2003).

Furthermore, it has also been found that ethical educational intervention at the tertiary level has been woefully inadequate in influencing the ethical behaviour of corporate and accounting professionals (Low et al., 2008; Leung and Cooper, 2005; McPhail, 2003; Craig and Amernic, 2002). One would assume that better prepared and ethically aware graduates would know how to take morally correct actions within the professional and corporate environment they work in. The contrary appears to prevail as Bryce (2003, p.17) aptly writes: "[S]upersmart, well-educated people, well-connected people ... and so stupid, so blind, so greedy. Their folly, their denial, their social climbing, their office affairs, and the corporate culture that pushed them into desperate deal making ..." This suggests that there is a deeper underlying issue that needs to be investigated when trying to understand what drives unethical actions/behaviour of accounting professionals and business executives. Do they deliberately choose to act in certain ways even though their actions might be deemed to be morally wrong and harmful to others because there is strategic legitimation of such actions by organisations and society and/or is it because they are socialised into accepting that such wanting actions are a 'norm' and part of the organisation's culture and political structure? It has even been suggested that many businesses may regard themselves as ethical if their legal staff can keep them safely within the law (McDonald, 2007). Under these circumstances, the test of whether an organisation is ethical or not is reduced to legal compliance.

There is extensive research literature (Shocker and Sethi, 1974; Guthrie and Parker, 1990; Patten, 1991, 1992; Lindblom, 1993; Gray et al., 1996; Deegan, 2002; Magness, 2006) that links legitimacy theory to corporate social responsibility. There is extensive 
use of the concept 'legitimacy' and 'legitimation' in organisational and management research literature (Narayan and Fahey, 1982; Zahra, 1987; Yeager, 1995; Perelman, 2005). There appears however to be a lack of research that links legitimacy theory to issues of unethical and even illegal behaviour of individuals in their organisational roles. Richardson and Dowling (1986, p.91) write that "in spite of the widespread use of the concept, however, it continues to be 'one of the great unanalyzed concepts' of organizational theory." Research linking this theory to organisational politics and strategy and the socialisation process of individuals also appear lacking. This paper will initially develop an understanding of how organisations seek to establish their legitimacy before explaining the legitimacy implications for organisational politics and strategy. The paper will then review literature that discusses legitimacy theory and how businesses develop strategies that legitimate the 'social contract' between organisations, their stakeholders and the wider society. From this discussion, the concept of a legitimacy whirlpool will emerge to highlight the ethical dilemmas that can confront individuals in the workplace because of a socialisation process that they undergo to 'fit' or be customised in their work environments.

The matters raised in this paper will assist in understanding why questionable unethical actions/behaviour continue to be practiced unabated by some accounting and corporate/business professionals despite having exposure to ethics education. There are ongoing calls for ethics education, for instance, in 1967, the Horizon for a Profession: The Common Body of Knowledge for Certified Public Accountants study indicated that if "[t]here were no ethical foundation to the profession then there would in fact be no profession” (p.14). The 1984 Bedford Report (sourced from Bloom et al., 1994) identified the need for higher education to develop the entering accountant's ability to think, to communicate, and to understand the nature and role of ethics. The Treadway Commission (also referred to as the National Commission on Fraudulent Financial Reporting, 1987) and the Accounting Education Change Commission (Sundem, 1990), both cited the need for young professionals to be able to make ethical and value-based judgements. The 2004 Ethics Education Task Force Report to the Association to Advance Collegiate Schools of Business (AACSB International, 2004) stated that business schools must encourage students to develop a deep understanding of the myriad of challenges surrounding corporate responsibility and corporate governance and to provide them with tools for recognising and responding to ethical issues, both personally and organisationally.

The 2006 Information Paper: Approaches to the Development and Maintenance of Professional Values, Ethics and Attitudes in Accounting Education Programs commissioned by the International Federation of Accountants (IFAC, p.13) found that there was overall "growing interest in professional and business programs responding to the call for greater ethics coverage in the curricula." As a consequence aspiring accountants and business executives will have exposure in ethical educational interventions not only during their tertiary studies but also in their professional preparations for institute membership. The paper argues that individuals are socialised, if you like, programmed and customised into acceptable norms of behaviour not for the benefits of society but more so for the organisations that they work for; because if they do not fit in the specific organisational political and strategic moulds then it is more than likely that they will become unemployed. In other words, employees must share and exhibit similar organisational values and culture. 


\section{Understanding how organisations seek to establish their legitimacy}

The importance of legitimacy stems from how organisations seek to legitimate their existence in society either in an explicit or implicit manner (Ruef and Scott, 1998; Suchman, 1995; Brinkerhoff and Brink, 2005; Hegtvedt and Johnson, 2000; Zelditch, 2001, 2006; Clay-Warner, 2006). Explanations provided of the concept of legitimacy focuses on the relationship of 'value' between them and society. In seeking to establish legitimacy, organisations commonly need to obtain support from society by "incorporating structures and procedures that match widely accepted cultural models embodying common beliefs and knowledge systems" [Ruef and Scott, (1998), p.878]. Suchman (1995), however, raises an interesting controversy with regards to how organisations may still retain legitimacy even when they deviate from appropriate values of some individuals. He contends:

\footnotetext{
"Legitimacy is a perception or assumption in that it represents a reaction of observers to the organisation as they see it; thus, legitimacy is possessed objectively, yet created subjectively. An organisation may diverge dramatically from societal norms yet retain legitimacy because the divergence goes unnoticed." [Suchman, (1995), p.574]
}

Importantly, Suchman (1995, p.574) presents that legitimacy is a social construction in that it "reflects a congruence between the behaviors of the legitimated entity and the shared (or assumedly shared) beliefs of some social group"; and postulates that "[a]n organization may deviate from individuals' values yet retain legitimacy because the deviation draws no public disapproval" (ibid). For instance, Sikka (2007, p.268) writes that auditing technologies have sought to foster trust and encouraged belief that companies were not corrupt and their directors were accountable to a variety of stakeholders even though these organisations with their enterprise culture and their pursuit of wealth creation indulged in "price fixing, tax avoidance/evasion, bribery, corruption, money laundering" and other practices that were "not necessarily being used in the wider social interest" (ibid). Suchman (1995) also states that the multiplicity of legitimacy dynamics enables the managers to strategically manoeuvre within their cultural environments to make a substantial difference in the extent to which organisational activities are perceived as legitimate, that is desirable, proper, and appropriate within any given cultural context.

Brinkerhoff and Brink (2005) provide three categories of legitimacy strategy type actions (see Figure 1) that managers can pursue to either increase or maintain legitimacy: conforming, informing and manipulating. Debatably, however, whether or not it is these types of strategic manoeuvrings by managers to achieve organisational legitimacy that society should become more concerned. Because it is without any doubt that the recent accounting scandals and corporate meltdowns are due to the strategic manoeuvrings by managers and accountants devoid of moral character. Sennett (1998, p.146) explains that there is a corrosion of character in modern capitalism because this type of system radiates indifference and that "[I]t does so in terms of the outcomes of human striving, as in winner-take-all markets, where there is little connection between risk and reward." Furthermore, Sennett (1998, p.148) concludes decisively that "a regime which provides human beings no deep reasons to care about one other cannot long preserve its legitimacy." These winner and loser stakes in business are played out in a capitalist market place; a fertile ground for individual greed. 
Figure 1 Management strategy for organisational legitimacy

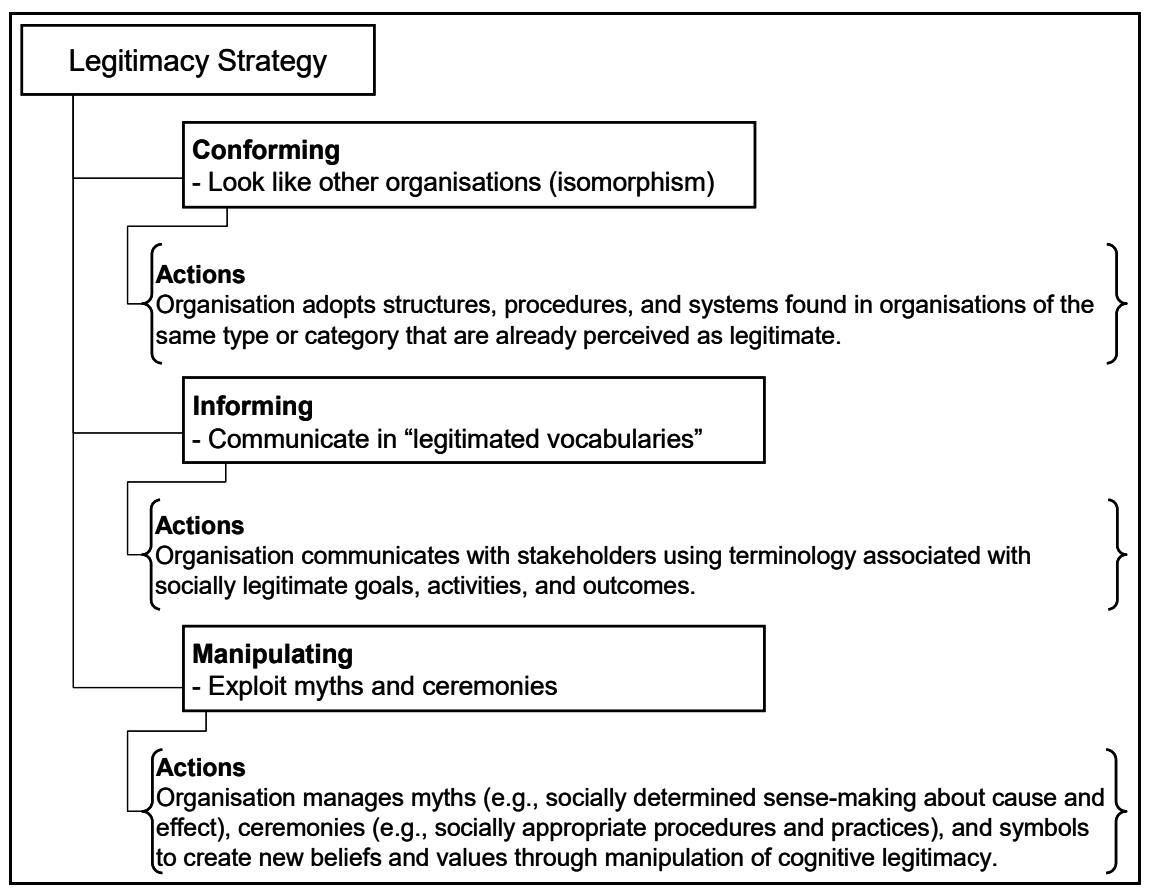

Source: Adopted from Brinkerhoff and Brink (2005, p.9, Table 2)

Given these circumstances, one can perhaps begin to appreciate why the better prepared and ethically savvy professionals are allowed to perpetuate ongoing accounting and corporate debacles as organisations they work in have provided them with legitimation strategies that they must follow if they wish to retain their positions within the organisation. Because "[m]any things can be legitimated: power, rewards, rules, status and sanctions" [Hegtvedt and Johnson, (2000), p.303]. Such legitimated structures within organisations allow and encourage business executives and accounting professionals to get involved with unethical actions and behaviour (as was made prominent by the Enron and Arthur Anderson debacles). Hegtvedt and Johnson (2000, p.303), also suggests that "a social order is legitimate or 'valid' when individuals believe that they must obey the operating norms or rules associated with that order (regardless of whether they believe them to be appropriate)." Clay-Warner (2006, p.213) referring to Weber's (1968) definition of legitimacy, Dornbusch and Scott's (1975) theory of authority and Zelditch and Walker (1984) and Walker and Zelditch's (1993) work on legitimacy as a multidimensional construct explain the important concepts of propriety, validity, authorisation and endorsement:

"Propriety is the individualistic form of legitimacy, defined as personal support. In contrast, validity represents legitimacy at the collective level. Validity is considered a collective process because it is determined by the views and actions of others - the group. Two primary sources of validity are authorization and endorsement. Authorization refers to support by those higher in the organization than the focal factor. Endorsement refers to support either by those at the same level in the organization as the focal actor or those lower in the organization than the focal factor." 
Zelditch (2001, p.4) explains legitimacy as one of the oldest problems in the history of social thought and explains that "[b]y the end of the fifth century BC, the Greeks were already asking under what conditions the use of power was legitimate." Zelditch (2001) also indicated that "the nature, conditions, and consequences of its legitimacy were the problem that both Plato's Republic and Aristotle's Politics were written to solve" (ibid); that "[ $\mathrm{t}] \mathrm{he}$ Greeks, in the first instance, were more concerned with how power ought to be justified" but that by "[t]he time of Aristotle's Politics, however, they also had an empirical theory of political stability in which authority was legitimate only if it was founded on constitutionalism and consent, and stable only if it was legitimate" and that therefore "by that time they had not only an empirical theory of political stability; they also had an empirical theory of distributive justice in which rewards were only just if they were proportional to contributions" (ibid). Fundamental to the concept of legitimacy is its effect on social stability in terms of both authority contributions made and rewards received in formal and informal settings. It is pertinent to note Warren's (2003) explanation on authority and how legitimation is established and exercised. Warren (2003) argues that the type of authority that an organisation has is largely determined and influenced by its leadership and with it, the culture and moral character of that organisation is established. The expression of this moral character and organisational culture is exhibited internally within the organisation itself as well as externally in how the organisation deals with outside parties. He subsequently explains that " $\mathrm{t}] \mathrm{he}$ term "legitimization" is indicative of this fact, in that, it implies legality or acceptance of a state of affairs; that the power is held "rightly" in the view of the community, and that the institutions of business are legitimized because they are granted by the consent of the governed" [Warren, (2003), p.156].

Figure 2 The legitimacy concept - a fully elaborated matrix (see online version for colours)

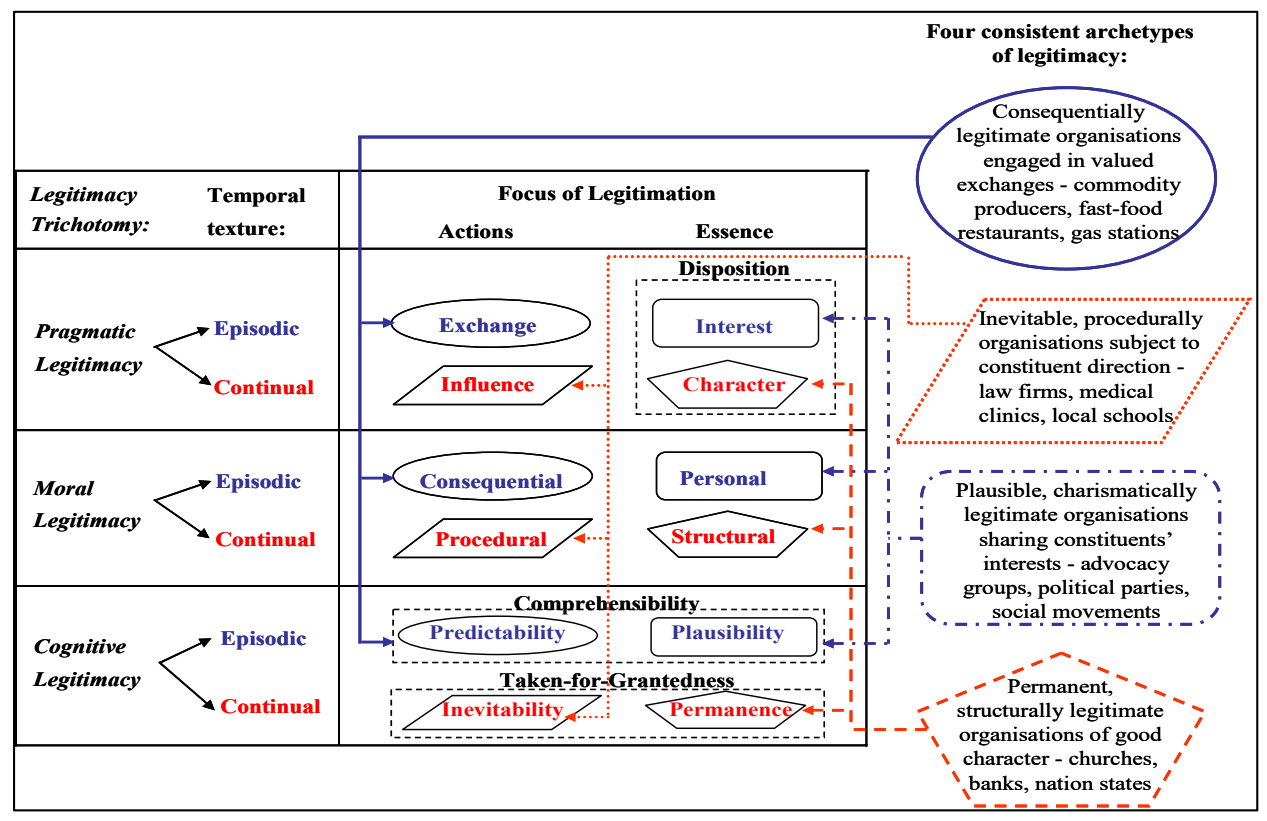

Source: Adapted and summarised from Suchman (1995, pp.583-584, Figure 1) 
It would appear that legitimacy can therefore also be viewed as a generalised perception or assumption and this is best explained by Suchman $(1995$, p.574) who writes that "the actions of an entity are desirable, proper, or appropriate within some socially constructed system of norms, values, belief, and definitions." This system of norms, values, belief and definition is not rigid and is a result of a complex dynamic struggle or response to both internal and external provocations, but in the main they are shaped by the organisation's leadership. We posit that it is through a socialisation process that individuals undergo within the organisations that enables them to acquire these legitimated norms and values. Furthermore, Suchman (1995) identifies three types of legitimacy: pragmatic, moral and cognitive; he suggests that in most real-world settings they co-exist and reinforce one another. His summary figure which depicts the various types of legitimacy along two cross-cutting legitimation dimensions so as to reflect the 'focus' that divides the organisation's actions from its essence and the 'temporal texture' that divides the episodic or transitory from the continual or long lasting basis has been adapted and reproduced in Figure 2. Figure 2 shows Suchman's (1995) identification of four consistent archetypes of organisational legitimacy employed by entities and illustrates that while there is a distinction in the research literature of three different types of legitimacy, they co-exist in most real-world settings.

The concept of legitimacy encompasses normative, legal, sociological, and cultural meanings. According to Brinkerhoff and Brink (2005, p.1), the classic reference to this concept was Weber (1947) who indicated that "[1]egitimacy has long been recognized as a core element in political and governance regimes, dealing with the relationship between social acceptance of regimes and institutions and their ability to exercise power and authority effectively." They also reasoned that "[o]rganizations that adhere to societal expectations (regarding mission, actions, structure, performance and so on), and that build an ongoing reputation for their appropriateness and correctness, are viewed as trustworthy and reliable, which contributes to being accorded legitimacy" [Brinkerhoff and Brink, (2005), p.2]. Hegtvedt and Johnson (2000) raise further important issues that may explain why individuals might choose actions that, on their own behalf, they might not have taken but, because of their professional and corporate affiliations, might be coerced to make. It is suggested that people are more likely to comply with rules for which authorisation and endorsement exist and that subsequently, "legitimacy of authority is fundamentally a collective process rather than a matter of private individual consent" [Hegtvedt and Johnson, (2000), p.303]. Authorisation or mandates given to individuals, acts, regulation, positions of power and organisations are conferred at the behest of others who are willing to subordinate or at the very least acquiesce to the transfer of authority and power. Where the mandate and authorisation to exercise decision making is strongly endorsed (regardless of whether this is real or perceived), individuals are more likely to comply, even if propriety is weak (Hegtvedt and Johnson, 2000). Individuals in organisations who exercise decision making are drawn into this socialisation process, which moulds them into accepting such strategies as normal behaviour (Anderson-Gough et al., 1998). Upholding organisational culture and 'toeing the company line' is all part of normal practice but what is more intriguing is that it is not only expected by managers but also widely accepted by society.

A case that clearly illustrates how a company can have in place legitimate business strategies but which by its very application brought about an undesirable and sad outcome relates to the recent situation of an electricity company disconnecting the power supply for a minor unpaid bill that caused the death of a woman dependent on electricity 
for the proper functioning of her oxygen machine. The case illustrates how it is important that people should approach moral problems in businesses more systematically and in a compassionate manner. It also highlights that business practices and corporate culture will only change if those engaged in the practices choose to change them. In particular, it is also important to remember business strategies and decisions need to include ethics (moral character) in dealing with what is 'right and wrong' besides what is legal or not in making those business decisions. Business ethics and the moral character of individuals within these organisations need to be key considerations such that important principles and guidelines are provided to assist people with making informed choices to balance economic interests (profit motive) and social responsibilities. An extract of the Weekend Herald newspaper dated June 2, 2007, Misa (2007, p.A1) clearly illustrates the dire consequences of such ill-informed business decisions:
“... When a contractor hired by Mercury Energy called at the Muliagas' house on Tuesday to cut off their power, Folole was breathing with an oxygen machine. She would have expected him to understand her plight. She had asked him, her children said, for a chance to pay off their overdue power bill ... the contractor was unmoved, that he went ahead and cut the power anyway. ... A little over two hours later, she was dead..."

What makes this situation appalling was the stance taken by the company with regards to this saga and this was reported in the same news article:

"Until yesterday, when Mercury Energy finally fronted up to the Muliaga family home at their Mangere home, on the advice of its Samoan workers, with $\$ 10,000$ towards the funeral, it had been more intent on being right than being sorry, insisting it was in the clear, that it had done nothing wrong." [Misa, (2007), p.A1]

It would appear that the 'company' was arguing that it conducted its business in a commercial environment in accordance with its strategies and company policies. It had done 'no wrong' in the manner in which it dealt with overdue accounts. Perhaps, the company was following the 'right' procedures (legitimate strategy) according to company policies and appropriate business practices to recoup overdue accounts; however, one could ask whether the company's actions were ethical, that is, 'good', given the ill health of one of the home owners. The reporter also writes in this article:

"As if this was about being right. No one at Mercury seemed to notice how
offensive it was for a state-owned enterprise which made a net profit of more
than $\$ 100$ million last year to wage a public relations battle against a grieving
widower who now has to support himself and four children on an income of
just over $\$ 400$ a week." [Misa, (2007), p.A1]

Even the then Prime Minister of the country joined in the discussion to denounce the moral behaviour of the company executives and its management policies. Trevett and NZPA (2007, p.B3) reported the Prime Minister, Helen Clark, as saying:

\footnotetext{
"When I saw the letter from Mercury Energy which stated bluntly that the contractor had seen the lady with the medical tube in her nose and still gone ahead and disconnected, I couldn't believe that a human being could do that."

"Helen Clark has also called for urgent advice on toughening up the regulations that cover the electricity industry, saying voluntary guidelines and protocols based on 'goodwill' were clearly not working."
} 
"Mercury Energy had a 'hard-nosed commercial attitude, and frankly, I don't want to be responsible for a state-owned enterprise that makes money out of misery."”

Why did the management of Mercury Energy and their contractor not feel any moral responsibility for this very unfortunate outcome? Bauman (1989, p.25) explains that "[t]he increase in the physical and/or psychic distance between the act and its consequences achieves more than the suspension of moral inhibition; it quashes the moral significance of the act and thereby pre-empts all conflict between personal standard of moral decency and immorality of the social consequences of the act." This may be true for the electricity company as the act of turning off the power was done by an intermediate person. This transfer of blame can be viewed as a mediation of action phenomenon where "without first hand acquaintance with his actions, even the best of humans moves in a moral vacuum ..." [Lachs, (1981), p.13]; but what of the contractor? Bauman (1989, p.21) explains the concept of organisational discipline is very strong and overwhelming; where "the demand to obey commands of the superiors to the exclusion of all stimuli for action, to put the devotion to the welfare of the organization, as defined in the commands of the superiors, above all other devotions and commitments." $\mathrm{He}$ quotes Ohlendorf (a German soldier involved in the Holocaust) to make emphatic his point: "I do not think I am in a position to judge whether his measures ... were moral or immoral ... I surrender my moral conscience to the fact I was a soldier, and therefore a cog in a relatively low position of a great machine" [Bauman, (1989), p.22]. Did the contractor perceive himself as a small cog doing contract work for a large corporate and that he had no choice but to obey orders having no regard to the moral significance of his own act? The actions of both the 'company' and the contractor when viewed in isolation were legitimate; otherwise both parties would have faced criminal charges. However, one does need to worry about the types of organisational politics and strategies that corporates have in place if ethical and moral responsibilities to society take a back seat in their entire decision making.

We also cite the following case in how an individual can setup a finance company legitimately to maximise his personal wealth earning potential. The phrase 'we are a legitimate business' is often used by business owners and directors as a defence when questioned about their operations. This case raises significant issues surrounding the organisational legitimacy and the types of strategies that individuals can put in place for themselves to operate legally but which has serious moral questions with regards to their wider responsibility to society. The following information was extracted from a newspaper report:

\section{Borrowers fight to keep homes}

A finance company that loaned money to low-income people prepared to sign over their homes faces high court action.

Low-income families seeking loans are losing their homes to a finance company in a complex deal under which they sell their houses to it and then try to buy them back...

One ... couple, $\ldots$, say they went to the company to borrow $\$ 10,000, \ldots$ The deal involved selling their Glendene home (which had a 1997 valuation of $\$ 154,000)$ to NZ debt repay for $\$ 215,000$ in February 1998 . They were to buy their house back for $\$ 225,000$ in 12 months after paying a $\$ 65,000$ deposit, which was non-refundable if the purchase did not proceed. In the interim, the 
couple, who were initially paying weekly mortgage payments of $\$ 250$, had to pay $\$ 460$ a week as a 'licence' to occupy their own home...

But Mr Hughes [one of the company directors] told the Herald that the company had acted legally and he rejected accusations that people had been duped into selling him their homes. He said the court action that the company faced was being taken only because of a technicality involving disclosure... "I won't have anyone telling me that I'm a fraud or that the thing has not been done properly because everything's been done [properly]." [Stickley and Yandall, (2001), p.A2]

The above company director stresses that the company had acted legally and had done things properly. In layman terms, to do something properly might suggest that the actions and behaviour of the individual were conducted in the way that they ought to within the acceptable norms of society. Zelditch (2006, p.324) writes that "legitimacy means that something is natural, right, proper, in accord with the way things are or the way things ought to be." He argued that anything could be said to be legitimate, that is, "acts, persons, positions, relations, the rules governing them, or any other feature of a group, including the group itself" (ibid) and that subsequently "the distinguishing feature of legitimacy is that if something is natural, right, proper, in accord with the way things are or ought to be, it is accepted not only by those who in some way gain from it but also those who do not" (ibid).

If one was to look at the word properly in terms of Zelditch's (2006) explanation of legitimacy where 'something is natural, right and proper in accord with the way things are or ought to be', then there is an underlying expectation of decency and respectability in the behaviour of individuals. However, it can be observed that the director of this company demonstrated an apparent lack of moral character in business ethics etiquette or even social responsibility. How decent or respectable can a business lending transaction be, if it involved making low-income families pay, in this couple's case, 2,250\% interest on a $\$ 10,000$ debt that had to be paid off within a year or risk losing their property? Indeed, where is the balance between economic interests and social responsibilities? McDonald (2007, p.12) explains the issue of appropriate business ethics succinctly:

\footnotetext{
"Many businesses may regard themselves as ethical if their legal staff can keep them safely within the law, but ethics is not only concerned with operating within, or just above, legal requirements. It involves more detailed questioning of actions and consequences that may not be covered by law."
}

The director of the company, however we might like to look and critique his business etiquette does have legitimacy to operate his company in the manner that he has chosen to. The existence of such businesses is a clear indication that there is implicit 'social contract' because it fulfils a need. The formal banking sector would not lend to people with dubious or no credit rating. Their only available source in securing loans is either through financial institutions such as banks or other lending institutions that charge exorbitant interest rates. These businesses may meet all legal requirements but are their practices moral and ethical? The business world does not see itself as guardians of moral or ethical values and there is no generally no onus to present itself in such a manner. In business practice, it would appear that it could be quite difficult for individuals to identify what is a 'good business action' as this identification is often dependent on the outcome (De George, 1995; Preuss, 1998). Solomon (2007, p.15) writes that "[i]n the real world, it is unlikely that businessmen and investors will be interested in acting ethically unless there are positive financial returns to be made from so doing." 


\section{The 'social contract' notion in legitimacy theory and its implications}

Research literature indicates that legitimacy theory is derived from political economy theory and was founded on the notion of a 'social contract' (Patten, 1991, 1992; Lindblom, 1993; Deegan, 2002; Shocker and Sethi, 1974; Guthrie and Parker, 1990; Gray et al., 1996). Shocker and Sethi (1974, p.67) provide a succinct explanation of the social contract concept:
"Any social institution - and business is no exception - operates in society via a social contract, expressed or implied, whereby its survival and growth are based on:
(1) the delivery of some socially desirable ends to society in general, and
(2) the distribution of economic, social, or political benefits to groups from which it derives its power."

In addition, Shocker and Sethi (1974) contended that in a dynamic society, neither the sources of institutional power nor the needs for its services are permanent. They expanded on this idea and indicated that "an institution must constantly meet the twin tests of legitimacy and relevance by demonstrating that society requires its services and that the groups benefiting from its rewards have society's approval" [Shocker and Sethi, (1974), p.67]. Deegan (2002) also explain that the insights provided by legitimacy theory emanate from the political economy theory, and citing Gray et al. (1996, p.47), define the 'political economy' (p.292) as "the social, political and economic framework within which human life takes place" (ibid). He argues that the perspective embraced in both the political economy theory and legitimacy theory is that society, politics and economics are inseparable. He further emphasises that economic issues cannot meaningfully be investigated in the absence of considerations about the political, social and institutional framework in which the economy activity takes place.

In support of Deegan's (2002) arguments, one can look to Guthrie and Parker (1990, p.166) who writes that "the political economy perspective perceives accounting reports as social, political, and economic documents" and that "[t]hey serve as a tool for constructing, sustaining, and legitimising economic and political arrangements, institutions, and ideological themes which contribute to the corporation's private interests" (ibid). The view that legitimacy theory was founded on the social contract notion is reinforced by Magness (2006) who indicates that legitimacy theory has its roots in the idea of a social contract between the corporation and society. Magness (2006) explains that legitimacy theory begins with the assumption that an organisation has no inherent right to exist and that this right is conferred upon it by society only when the company's value system is perceived to be congruent with that of the society in which it operates. This right can be revoked if the company is thought to have breached any of the social contract terms.

The dramatic collapse of Arthur Anderson illustrates this case in point succinctly. Up until the early 2000s, this global conglomerate was one of the 'big five' accounting firms. It could be argued that the accounting firm's involvement in the Enron debacle led to breaches of its social contract with society, its profession's code of ethics and the law. As a consequence, this accounting firm no longer exists because its professional reputation was so tainted; the society in which it operated no longer had any confidence in the firm's ability to conduct fair and proper business. Grey (2003) offers a cultural explanation of Enron's auditors [Arthur Anderson] that focuses on the social processes and practices 
within the internal organisation of big audit firms which brought about this accounting firm's demise. According to Deegan (2006, p.161), "legitimacy theory is a theory that gives explicit consideration to the expectations of society (as embodied in what we will refer to as the 'social contract' between the organization and the society with which it interacts), and whether an organization appears to be complying with the expectations of the societies with which it operates." Wilmshurst and Frost $(2000$, p.11) confirm this view when claiming that "[1] egitimacy theory has come to stress how corporate management will react to community expectations" and that "firms will take measures to ensure their activities and performance are acceptable to the community" (ibid). Furthermore, Ratanajongkol et al. (2006, p.69) writes that "[w]ithin legitimacy theory, the organization is seen as part of a broader social construct whose expectations it must meet if it is to have ongoing operations without excessive societal sanctions being imposed." They argue that the assumption of legitimacy theory stems from the notion that organisations do not have an inherent right to exist but only do so with the sanction of society and that if an organisation perceives that its legitimacy is under threat then it can adopt numerous strategies.

Figure 3 The 'social contract' between organisations and society - legitimacy theory (see online version for colours)

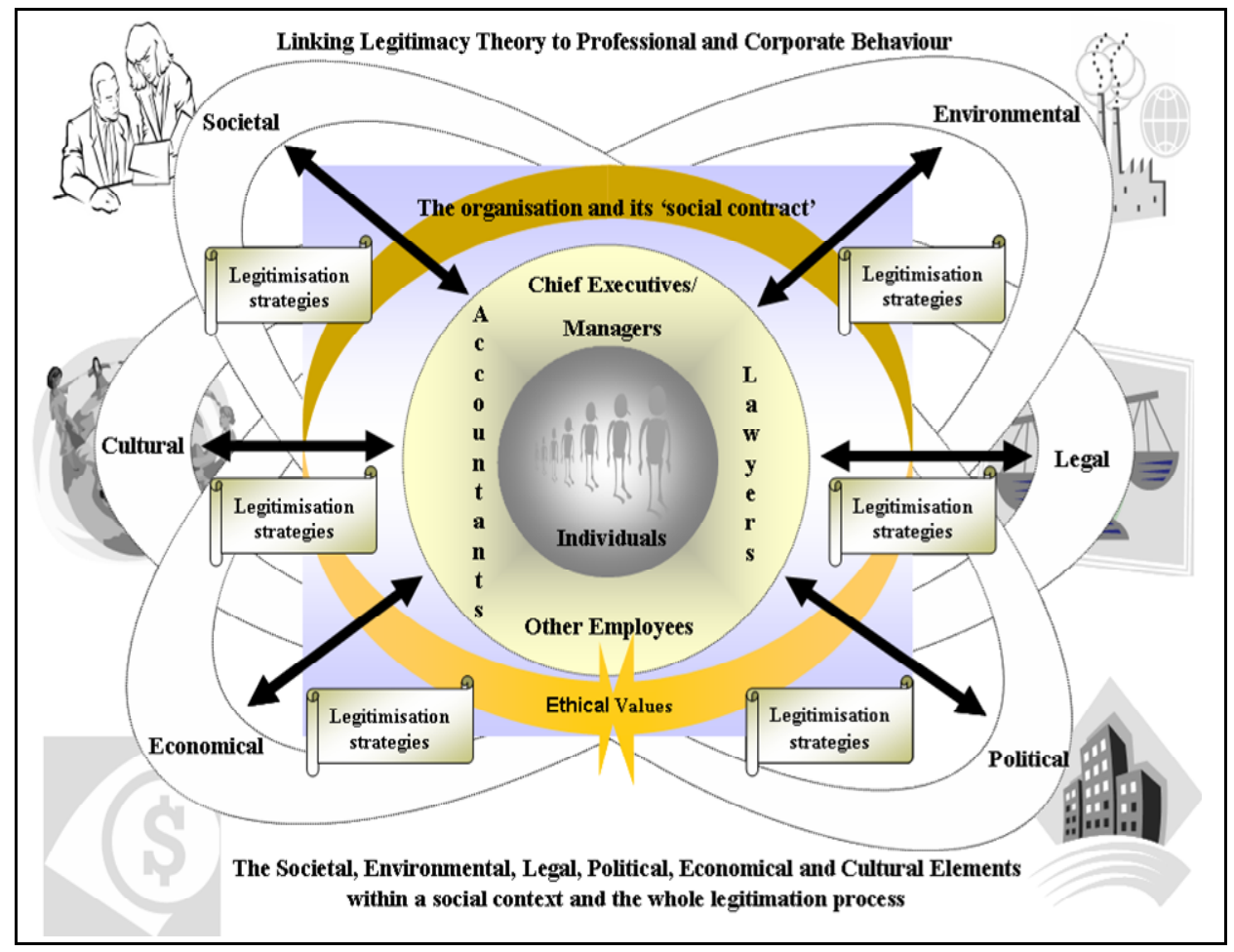

The encapsulation of the social contract notion between the organisation and the broader social construct within which the organisation operates is presented in Figure 3. Alam (2006) explains that the role of management, seen from social contract and legitimacy perspectives, needs to be broadened to satisfy special obligations to other stakeholders 
and not just merely aimed at the maximisation of wealth for shareholders. Figure 3 incorporates societal, environmental, legal, political, economical and cultural elements for consideration within the broader social context. These elements encompasses much more than just the social, political and economic framework put forward by Gray et al. (1996). In addition, it is presented that the core [emphasis added] involves the individuals within the organisation who are the key players (that is, leadership and contentiously may be the chief executives, managers, lawyers, accountants and to a lesser extent, other employees within the organisation) in any of the activities conducted by the organisation. These key players should subsequently be seen as the core [emphasised again], that ensures that the organisation is fulfilling its 'social contract' with its stakeholders. Ultimately, the key issue in how this 'social contract' is transacted depends on the character of this group of individuals that make up the leadership. The challenge for these players will be exercising appropriate ethical values that would allow for a 'genuine and true honouring' of its social contact with society. Key professionals are extensively involved in the legitimation process for organisations (see Figure 3). Emphatically, these key professionals should not only have strategy but strength and depth in their moral character so that they can fulfil their social contract obligation to society. It is interesting to note at this point, Spence et al.'s $(2010$, p.80) critique of legitimacy theory which they termed 'coconut radio'. They state: "[I]t has become clear recently that legitimacy theory derives from a premise that does not see much in the way of antagonism at all" [Spence et al., (2010), p.82]. By its very nature, antagonism is not a feature of legitimacy theory. The agreements in the social contract regardless of whether it is explicit or implicit suggest that relationships between organisations and the society in which it operates in are generally conciliatory. Conflicts only occur when the social contract is broken. This position meshes with bureaucratic theory, which maintains that one of the sole aims of any organisation is its existence. Key individuals are tasked with ensuring its survival and growth, and in their normal activities, they will 'tick all the right boxes' to demonstrate the organisations' continuance in fulfilling their social contract.

Legitimation process and strategies that the organisation will subscribe to, in order to bring about legitimacy for its existence, also need to consider carefully the cultural and ethical values of the people in the society in which it operates. The two-way arrows suggest that legitimisation strategies can be proactive and reactive (Suchman, 1995). This is to say, in some instances, the organisation may put forward legitimacy strategies in advance to address the social contract it has with society; for example, the organisation might put in place policies that address cultural issues. In New Zealand, the Maori culture and language are also very important considerations for organisations even though the main medium of communication is the English language. Another example is shown in the General Election booklet provided to eligible voters in the country. To address cultural diversity, the government provides information in a number of different languages to address as wide as possible the different ethnic groups of people that might want access to information about the voting system in New Zealand.

On the other hand, some organisations might choose a reactive strategy and wait to see if issues are raised before working to repair or maintain their legitimacy by bringing in new organisational policies that will address concerns raised by the particular group of stakeholders. In other cases, organisations might be proactive and also reactive in their legitimisation strategies as they would continually work at maintaining societal expectations and ultimately their right to exist. An excellent illustration (but which some would argue sits on the 'murkier' or 'darker' side of accounting and legal services) of 
where organisations might be both proactive and reactive in their legitimation strategies can be seen in the types of tax avoidance schemes and aggressive tax planning strategies promoted by accounting and legal firms which become hashed and rehashed for suitable 'legal arrangements' that will again allow for the legitimation of their social contract when tax legislation disallows such schemes and strategies. Consider the New York Times headline: 'Big accounting firm's tax plans help the wealthy conceal income' and the following extracts from this article:

\begin{abstract}
"In private meetings with wealthy Americans and their financial advisors, the accounting firms Ernst and Young has for months been selling four techniques to eliminate or sharply reduce incomes taxes. Ernst and Young says the techniques are legal and proper. ... Without these deals, the money would be taxed at rates from 18 to 38.6 percent. The savings are significant, and so are the profits for Ernst and Young and the law firms, banks and currency traders participating in the arrangements. ... The other surviving big four accounting firms - Deloitte and Touche, KPMG and PricewaterhouseCoopers - sell their own techniques to reduce taxes for the wealthiest Americans." [Johnston, (2002), n.p.]
\end{abstract}

Johnston (2002) also wrote that some of the methods the accounting firms sold in recent years had been identified by the treasury as improper and were ordered to shutdown. However, it would also appear from Johnston's (2002) discussions that further techniques were continually being developed to benefit their wealthy clients and that such techniques were rarely made public except to selected clienteles who must sign confidentiality agreements. Mansell (2004, n.p.) writes that Ernst and Young who are regarded as an aggressive promoter of tax avoidance schemes defended its position by saying: "Businesses are taxed under the law and are entitled to plan within the law."

Important legitimisation strategies issues have been raised by Deegan (2006, p.171) when he emphasises that "different managers will have different perspectives about the terms of the social contract and hence will adopt different strategies to ensure that organization's operations are acceptable to various stakeholder groups." Deegan (2006) explains by contrasting the legitimation strategies of an armaments manufacturer with 'The Body Shop' where obviously the products of armaments manufacturers are designed to kill and as such this organisation arguably has less to worry about in terms of its legitimacy as its business intentions are obvious and the majority of society widely accepts the necessity for such industries. In contrast, 'The Body Shop' trades on its reputation in caring for the environment, society, and the welfare of animals where policies and strategies were developed and highly publicised, in the market place, to demonstrate that this organisation is corporately and socially responsible. The presence of a social contract demands that organisations consider not only the rights of investors but also the rights of the public at large (Deegan and Rankin, 1997) as they are parties to the contract. If an organisation fails to operate within acceptable bounds of behaviour, in theory, society would act to force a change in the organisation's behaviour or have it removed. Deegan and Rankin (1997, p.567) stressed the ways in which organisations operated and reported are very much influenced by the "social values of the community in which it exists." This latter point is important as it might explain why corporate debacles and accounting scandals continue to occur. If societal/community values are not 'appropriate' (that is, has dysfunctional ethics and moral values), then individuals within organisations take their guidance for perceived 'legitimate actions' directly from the societal values present in their surroundings. For instance, the ready acceptance of tax 
havens and aggressive tax planning schemes by many in society encourages accounting firms and large corporations to continue such ethically questionable professional and business practices.

The legitimacy theoretical framework is relevant and could explain what is considered acceptable, unacceptable actions and the general behaviour of individuals in the corporate and professional environments. Gray et al. (1996) indicate that it is the moral responsibility of companies to make corporate social disclosures beyond the minimum legal requirements. However, discussion on the moral responsibility of companies is an abstract concept because companies as such are not living creatures that conduct activities; it is humans who operate and bring companies to life through their actions. This argument is summed up aptly by Perelman (2005) who indicated that although corporations obviously are not human, they can wield enormous power well beyond what any human being could dream because of the charters that grant them the possibility of immortality not afforded to ordinary human beings. He writes (citing Baker, 2002):

"During the height of the scandal involving Enron's multibillion-dollar frauds, a Wall Street Journal opinion piece entitled 'Corporations aren't criminals' noted: 'Under the common law, a corporation could not be guilty of a crime because it could not possess mens rea, a guilty mind' (Baker, 2002)." [Perelman, (2005), p.80]

If a corporation cannot be guilty because it does not possess a 'guilty mind', then the question of who is indeed guilty of the crime must turn to the 'actors' within the organisation. Subsequently, one must link the concept of 'moral responsibility of companies' directly to the moral responsibilities of the individuals within the organisations (companies) if any real progress is to be made in understanding the issue of who indeed should be deemed guilty or accountable for the financial losses to investors and the loss of jobs for the employees of the affected organisations. Voluntary disclosures of social and environmental information will only arise from individuals within organisations seeking ethical business practices and therefore, should be intrinsically linked to the individuals' own ethical actions and behaviour. However, Hooghiemstra (2000, p.56) explains that “... research by Deegan and colleagues $(1996,1998,1999)$ and Patten $(1991,1992)$ indicate that the amount of environmental and social disclosures is particularly high when the organization or the industry in which it operates has to face a predicament, e.g. environmental pollution, violation of human rights, prosecution of the company, et cetera."; thereby suggesting that the higher number of environmental and social disclosures is not so much a reflection of individuals within the organisations seeking sound ethical business practices but more an outcome particularly when the organisation or the industry in which it operates has to face a predicament. Ratanajongkol et al. (2006, p.69) also highlights that "a number of papers (Hogner, 1982; Deegan and Rankin, 1996; Brown and Deegan, 1999; Savage et al., 2000; Wilmhurst and Frost, 2000; Deegan, 2002; O’Donovan, 2002) have identified specific types of social responsibility disclosures that have appeared within annual reports and which have been explained by the respective researchers as being part of the portfolio of strategies undertaken by accountants and managers to bring legitimacy to, or maintain the legitimacy of, their respective organizations" [emphasis added].

Emphatically organisations should be viewed as inanimate objects, which by themselves cannot act and legitimise actions on their own. Managers, accountants and 
individuals in key leadership roles in organisations are acting as legitimising agents on behalf of these organisations. What influences, as well as how these individuals make their decisions determines the organisations' culture and business behaviour. Williams (2002) reinforces the need to focus accounting ethics research on the decision processes of individuals. Citing Adams and Balfour (1998, p.168), Williams (2002, p.6) observes:

\begin{abstract}
"Why is the individual conscience primarily responsible for ethical behaviour when it is political and managerial authority that are responsible for public policy and organisations? The answer is that operationally (theory in use); the central value is the primacy of legitimated authority. This is buttressed by the focus of the utility-maximising individuals as the locus of ethical decision making. In short, the ethical problem is construed as one of individual conformance to legitimate authority as a function of self-interest."
\end{abstract}

Brown (1997) explains that the self-esteem of individuals (a concept which arguably is closely related to self-interest) and the participation of these individuals in groups and organisations throw new light on the dynamics by which collectivities gain and maintain internal legitimacy because "organizations offer individuals and groups the opportunity to share in the means by which their self-esteem may be continuously recreated and sustained in ways that make it motivationally compelling to accept their organizations as desirable, proper, and appropriate - that is, as legitimate" (p.664); this suggests that a socialisation process is enacted upon individuals. Brown (1997) also argues that the exchange relationship view of legitimacy is most plausible with the assumption that rewards function best by reinforcing the self-esteem of individuals. Citing a number of researchers and their arguments about why individuals attribute legitimacy to their organisations, Brown (1997, p.664) suggests "that the provision of rewards to participants, the construction of a morally acceptable image with which members can identify, and the offer of explanations that make working life seem meaningful are valuable in and of themselves"; again this can be viewed as the socialisation process that contributes to the 'making up' of the individual [see Anderson-Gough et al. (1998) discussion on the making up of accounting professionals]. Brown (1997, p.664) explains further:

"Traditional accounts of the reasons why members attribute legitimacy to their organisations tend to suggest that these reasons are:

(1) based on rational calculations of self-interest (Dowling and Pfeffer, 1975; Emerson, 1962; Pfeffer and Salancik, 1978; Wood, 1991);

(2) a detection of congruence between the members' notions of what is right and good and the consequences, procedures, structures, and personnel associated with the organisation (Aldrich and Fiol, 1994; Parsons, 1960; Scott, 1977; Scott and Meyer, 1991); and

(3) because the organisation offers explanations and models that allow participants to reduce anxiety and provide meaningful explanations for their experiences (Scott, 1991; Suchman, 1995; Wuthnow, Hunter, Bergeson and Kurzweil, 1984)."

The words 'self-interest', 'members', 'participants' and 'organisations' have been italicised to stress the roles that individuals in organisations play in the legitimation of business activities (see again Figure 3). This reinforces Magness' (2006) explanation of the role of legitimacy theory within established accounting literature. She highlights that early accounting theorists identified the users of accounting information as being mainly 
creditors and shareholders (financial stakeholders) but that, over time, users expanded to include insurers, suppliers, consumer associations, regulators, environmental groups, and the media, plus others such as professional accounting bodies. Because of the broadening of users under the stakeholder concept, Magness (2006) indicates, the objective of accounting has expanded to include not only information that is financial in nature but also information that satisfies increasing social interests. This has placed considerable pressure on company managers to find ways to respond to this diversity of interests. She explained that "[1] egitimacy theory was subsequently integrated into the accounting literature as a means of explaining what, why, when, and how certain items are addressed by corporate management in their communication with outside audiences" [Magness, (2006), p.542]. Consequently, it would appear that legitimacy theory has its roots in the idea of a social contract between the corporation and society. Therefore, organisations and corporations need to work on legitimation strategies to 'honour' their social contract with society; the extent of these strategies, some of which have hidden agendas raises ethical and moral issues. This area of concern and how it relates to the legitimation of organisational politics and strategies is explored next.

\section{The legitimation of organisational politics and strategies}

The formulation of strategy is viewed as a political process, because fundamentally, organisations are political entities with a coalition of interests and demand emanating from within and outside organisations and that, therefore the content of strategic decisions can be viewed as an outcome of transactions of power and influence (Narayan and Fahey, 1982). Zahra (1987) writes that there is a growing realisation that organisational politics and their tactics influences the choice of corporate strategic profile which ultimately determines the success or failure of the chosen course of action that subsequently impacts on organisational performance. While Cavanagh et al. (1981, p.364) present that current management theory focuses on the value of outcomes rather than on the value of the means chosen whereby political uses of power demand explicit consideration of ethical restraints, they also argue that "in spite of formal systems designed to control the use of power, organizational members can and do exercise political power to influence their subordinates, peers, superiors, and others." They write that "there are a host of political actions that may be justified in the name of organizational survival that many would find morally repugnant" (ibid). Butcher and Clarke (1999) illustrates what these political actions might be by indicating that it was common enough to hear managers describe organisational politics in highly emotive language which included "'back stabbing', 'secrecy', 'manipulation', 'self-interest”" (p.9) and that "cynicism and mistrust are commonplace reactions of many 'ordinary' people" (ibid). In a similar manner, Gray and Ariss (1985, p.707) explain that "organizational politics consist of intentional acts of influence undertaken by individuals or groups to enhance or protect their self-interest when conflicting course of action are possible."

An understanding of legitimacy theory is therefore needed to enable clarity and provide an explanation as to why unethical practices and behaviour by accountants, lawyers and business executives have continued despite recent significant developments and advances in business and management (including accounting) educational programs. Because there should, indeed, be many more educated and ethically aware individuals working in organisations and society. It may be that individuals within their respective 
organisations seek to legitimate their actions in one way or another. Pava and Krausz (1997) asserted that it was becoming impossible to evaluate business activities from a traditional ethical perspective because of human nature and human influences upon these activities. Jensen and Meckling (1994, p.7), identified by Pava and Krausz (1997, p.338) as pioneers in modern finance and agency theory, unabashedly described human beings in the following manner:

\begin{abstract}
"Like it or not, individuals are willing to sacrifice a little or almost anything we care to name, even reputation or morality, for a sufficiently large quantity of other desired things, and these things do not have to be money or even material goods. Moreover, the fact that all individuals make trade-offs (or substitute in virtually every dimension imaginable) means that there are no such things as human 'needs' in the sense that word is often used. There are only human wants, desires, or, in the economists's [sic] language, demands." [italics and emphasis as per original quote]
\end{abstract}

Perelman (2005) presents a more controversial viewpoint regarding the role that managers must play in the corporate world. Following on from his earlier reference to corporations lacking 'mens rea', "[I]n the eyes of some judges, the law goes even further than merely ruling that corporations that violate the law lack a guilty mind" [Perelman, (2005), p.80]; "[T] hey insist that corporate managers, who do possess a mens rea, actually have an ethical responsibility to violate the law when doing so will prove profitable for stockholders" (ibid). Profit maximisation is a very strong motive and if managers have been given such 'legitimation' (that is, 'an ethical responsibility to violate the law', italics for emphasis) by certain groups of stakeholders in society, then it is not too difficult to understand why corporate and accounting debacles continue to happen. Yeager (1995) illustrates how one manager sought to 'legitimise' his own as well as his superior's actions by repeatedly asserting that the actions taken were not unethical and had nothing to do with 'basic badness' (lack of moral character) because of higher organisational purposes (that is, strategies) and because people's jobs were saved:

"One middle manager falsified the profits of his unit by large amounts under pressure from his superior in a manner that violated standard accounting procedures and federal law (i.e. by manipulating several accounts). This individual had earlier asserted that he had never felt pressure to compromise his personal values in his work with the company. But this situation clearly gave him pause as he described it later in the interview: '[What I was asked to do] was wrong ... [I thought it was] unethical, if you will. I had to compromise my financial ethics.'

This manager clearly saw the action as wrong - and did vigorously resist it at first - but placed his struggle in terms of professional norms. Indeed, he appeared to wrestle with the concept of the ethical in his attempt to ward off the personal moral implications of the situation. Thus, while financial ethics are consequential and their breach is problematic to this individual, basic badness had nothing to do with it. This interpretation was perhaps more pronounced in his assessment of his superior's role in making the decision:

What he did was not unethical. It just ... um ... well, he knew exactly what he was doing. It's not that he did it out of ignorance or anything. What he did was not unethical. What he did was he made the best of a bad situation without having to sacrifice the company's progress. If we wouldn't have gotten the [profits increased this way], I don't know how we would have gotten the money. We might have had to cut back on some things we didn't want to sacrifice, like our marketing budget, or on people. You know, I mean the 
alternatives to [the decision] were probably a lot uglier." [Yeager, (1995), pp.157-158]

This situation surely illustrates Perelman's (2005) case in point, that is, that corporate managers are applying their 'ethical responsibility' but for the organisations they work in, to violate the law in order to show profits, thus fulfilling required organisational strategies. There appears to be no consideration of their 'ethical responsibility' to the wider society. Yeager (1995) subsequently notes that the deed was clearly wrong in the face of law and professional norms but that the manager tried to dilute the 'badness' of the unethical situation by asserting that his colleague's action served 'legitimate' higher organisational purposes. He explains that there may be two perspectives provided in the interpretation of this situation whereby the first perspective "interprets this as little more than after-the-fact rationalization by someone who should have shown more moral courage" [Yeager, (1995), p.158] but the second perspective would see the situation as being more complex:

"True, it involves illegitimate extension of the logic of moral justification from reasonable contexts of real dilemmas to what is essentially a pseudo-conflict. But the extension is facilitated not only by the existence of such logic and real conflicts but also by the difficulties entailed in separating true dilemmas from their imitators (not all so pale) and heightened by (while also contributing to) the failure publicly to deliberate moral questions in organisational settings."

The illustration extracted from Yeager (1995) makes the emphatic point that if one is to try and understand why there is still so much unethical behaviour prevailing in business when supposedly there should be better educated, ethically aware and more socially responsible individuals in society, then one should look at the issues raised under the concept of legitimacy and legitimacy theory. If one was to focus on the unethical behavioural aspects of accounting and business professionals and use legitimacy theory to explain this issue, then it can be presented that individuals within organisations appear to work through a legitimation process, involving either proactive or reactive legitimacy strategies (or both) that allow their 'social contract' with society to become 'acceptable' even though their actions might be unethical and highly questionable and devoid of moral character. This pertinent question therefore requires asking: if you must be without one, which should it be, strategy or character?

Currently it would appear that there are business executives and company directors who have been paid huge salary packages, bonuses and dividend returns for their key roles in managing their organisations and yet are able to insulate themselves from personal financial crisis even though the very organisations that they managed have been placed into receivership or liquidation. These executives and directors continue to enjoy the excesses of good living and lifestyle (for instance, exclusive golf tours, expensive cars, properties worth millions, lavish birthday parties and the like) and yet they can have the gall to inform their shareholders that it was very unlikely that they would be receiving much of their investments back in cash. It would appear that these individuals have put in place strategies that protect them while others (shareholders, creditors, the Inland Revenue Department and other stakeholders) stood to lose the lot. Questions should be asked of these executives and directors, and whether or not any of them have any moral conscience or strength in moral character when undoubtedly anyone with any financial nous can see where the cash in these failed organisations have been filtered out to. For instance, the recent media extracts with regards to the troubled Hanover Finance 
Company showed that it owed $\$ 550$ million to their investors when their operations were frozen in mid 2008. Hotchin, one of the directors of the failed company continued to spend up large on his mansion worth $\$ 50$ million as reported in the media:

\begin{abstract}
"During a Hanover Finance meeting last year, Hotchin took a question from an angry investor who asked whether the businessman would sell his Paritai Drive home to repay investors.

Hotchin replied: 'I wish to hell I'd never bought it. It's half-finished and couldn't be sold. Our intention is to finish that house and to live in it as our home.'

But in an interview last December, Hotchin defended the mansion in progress. 'The house at Paratai is obviously an easy place to point. It is frustrating for me. What do I do? You can't leave it unfinished. It is unsafe." [Marshall, (2010b), p.A2]
\end{abstract}

'What do I do?' Front page headlines in May 16, 2010 Sunday Star Times: 'Inside Hotchin's Hawaiian hideaway' where “[O]ne of those burned by the failure of Hanover says it has been a 'kick in the guts' to know that Hotchin has been building a $\$ 30$ million mansion in Auckland's Paritai Dr, planning a $\$ 13.8 \mathrm{~m}$ holiday home on Waiheke Island, and has for the past month holidaying in luxury in one of Hawaii's most expensive homes [reported to be at $\$ 43,000$ a month]" [Marshall, (2010a), p.A1], suggests that there should really be only one answer to that question! Lewis and Meng-Yee (2010), has as their headline in the Herald on Sunday: "\$405k for Hotchin to get away from it all" and reports that "Marvyn Crone, a Hanover investor who lost about half of her and husband Rowland's investments when the company collapsed in 2008, said she'd like to see Hotchin come back to New Zealand to "face up", (p.7). Larson (2010, p.10) portrays a sadder circumstance when she wrote: "Often forgotten as pundits bandy around the big numbers - $\$ 6$ billion lost by New Zealanders in finance companies now belly-up and floating in their toxic pond - are the real stories of hardship among the ranks of 'small' investors. Like elderly Gerrit Bax, who stopped eating and died weighing $43 \mathrm{~kg}$, after finding out his life savings in Hanover would not be available for his nursing care." "It is frustrating ...', only a truly ethical responsible 'director' with a moral conscience and strength in moral character would not have to deal with such a 'frustrating' issue - to give back what rightly belongs to the investors.

The question that therefore needs to be asked is why do and more importantly, how can the majority of directors walk away from their failed companies without a backward glance at the serious consequences that they leave behind in terms of unpaid creditors and investors who have lost their life savings from their investments into these companies? Do the sections under directors' duties in the New Zealand Companies Act of 1993: "Duty of directors to act in good faith and in best interests of company" (Section 131) and 'director's duty of care' where "A director of a company, when exercising powers or performing duties as a director, must exercise the care, diligence, and skill that a reasonable director would exercise in the same circumstances taking into account, but without limitation, - (a) the nature of the company; and (b) the nature of the decision; and (c) the position of the director and the nature of the responsibilities undertaken by him or her" (Section 137), not capture the ethical and moral responsibilities that directors should have towards their financial and non-financial stakeholders? It would appear not.

The arguments put forward by Yeager (1995) and Perelman (2005) seems to suggest that there is a 'legitimacy whirlpool' that can lure (those that are willing participants) or 
drag (those that are unwilling but are coerced into doing so) individuals into its depths because of legitimation strategies that can be used by organisations to justify their existence and survival. Sims (2002) emphasised that undergraduate and graduate students must learn how to develop a certain amount of resiliency to comfortably resist external pressures to act immorally. The concepts that underpin legitimacy theory, indeed suggest that these future accounting and business professionals will need a lot of resilience if they are to withstand legitimation strategies that may seem 'acceptable' and 'above board' to the organisation and certain groups in society, but which can be argued to be questionable strategies in terms of the negligence of their wider responsibilities to society.

Figure 4 The legitimacy whirlpool

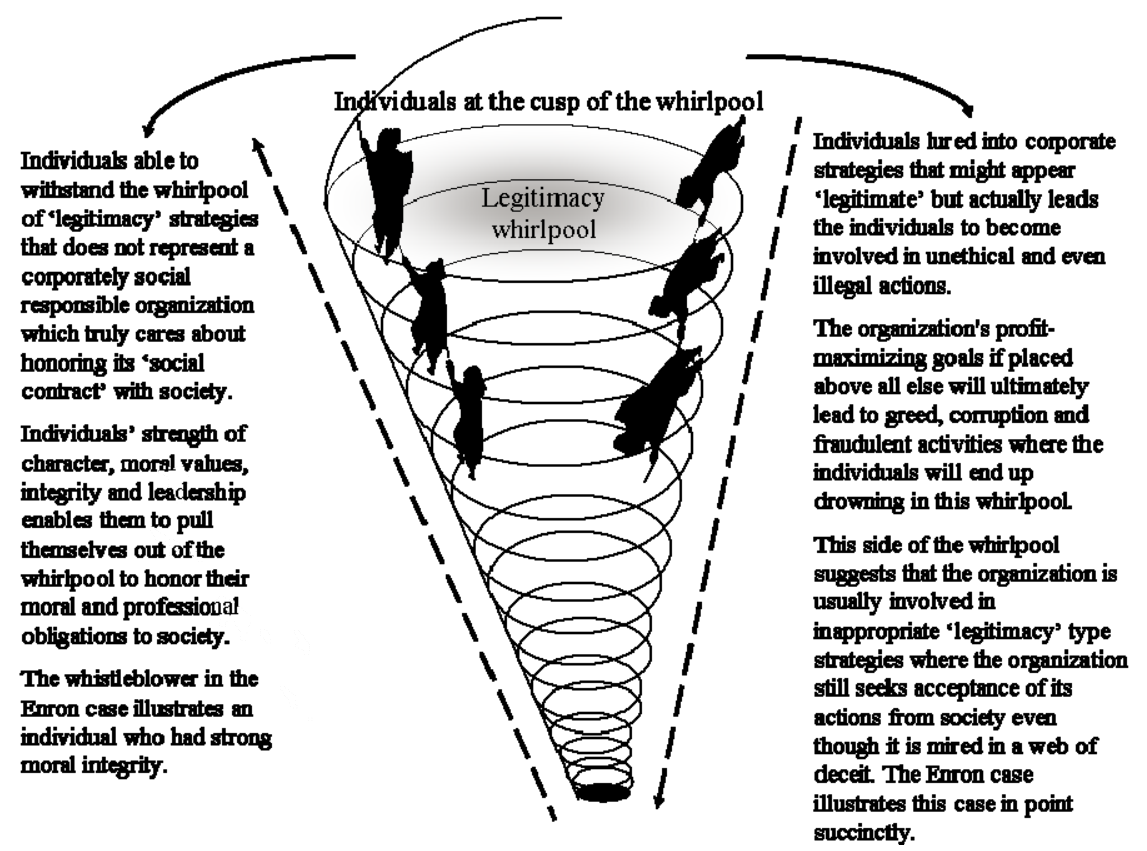

Figure 4 illustrates the type of issues that individuals may confront in the legitimacy whirlpool. Figure 4 illustrates that individuals who have stronger moral values and character may indeed more truly honour their 'ethical responsibilities' to society whereas individuals lacking this moral strength might instead focus on their 'ethical responsibility' to the organisation by complying with business strategies that are devoid of appropriate moral values in terms of their consequences on wider society. Such individuals will subsequently drown in the depths of the whirlpool because the organisation will ultimately collapse when society no longer accepts its legitimacy and terminates its rights to existence.

The recent history of high profiled corporate scandals relating to Enron, WorldCom, Tyco International, Arthur Andersen and other collapsed corporates showed overwhelmingly that their leaders were exemplars of egregious moral as well as legal wrong doing (Donker et al., 2008). Boatright (2000) argues that individuals when faced with an ethical problem need to make a decision that is ethically defensible but which at the same time should still satisfy the company's legal obligation as well as the legitimate 
demands of economic performance. To avoid being dragged into the mires of the legitimacy whirlpool, accounting, legal and corporate professionals need to develop business strategies that incorporate emphasis on business ethical and social responsibilities such that they become more grounded morally in their actions and behaviour thus giving them better clarity in their strategic daily economic activities and decision making. Business strategies should not only be guided by economic and legal imperatives, but also by an overarching moral and ethical code so that individuals within organisations behave as good socially responsible citizens. However, how is it that these individuals who have received significantly more accounting, business and ethics education than their historical counterparts, are unable to withstand the pull of the legitimacy whirlpool and become drawn into such unethical and questionable legitimated organisational politics and strategies? Attempts to highlight the socialisation process that plays an important role in the 'making up' of these individuals and how they become drawn deeper into the legitimacy whirlpool is discussed in the next section.

\section{The 'make up' of individuals - organisational and professional socialisation into acceptance of legitimation strategies}

Why do individuals accept and implement the legitimation strategies put to them by their employing organisations? As professional accountants, managers and business leaders who are highly educated and trained, how do they allow themselves to be dragged into the mires of the legitimacy whirlpool? Surely, these individuals are able to distinguish organisational politics and strategies that benefit society as opposed to those that have dire consequences for society. Anderson-Gough et al. (1998) present that accounting professionals but which would also generally apply to all professionals, maintains that a socialisation process exists within an organisation that contribute to their 'making'. These authors explain socialisation as a "process of learning the appropriate way of doing things, of learning how to be in a certain environment, of internalizing the norms, values and beliefs of a culture" [Anderson-Gough et al., (1998), p.21] and that it is "the process which involves individuals learning to conform to prevalent norms" [Anderson-Gough et al., (1998), p.15]. This explanation of socialisation is reinforced by Weidman et al. (2001). They defined socialisation "as the process by which persons acquired the knowledge, skills, and dispositions that made them more or less effective members of society" [Weidman et al., (2001), p.4] and that this process "can be viewed as 'an upward-moving spiral' carrying the neophyte through recurring processes toward the goal of professionalization" [Weidman et al., (2001), p.5]. They also explained that socialisation involved a subconscious process "whereby persons internalize behavioural norms and standards and form a sense of identity and commitment to a professional field" [Weidman et al., (2001), p.6]. Anderson-Gough et al. (1998, p.127) takes the explanation of the socialisation process further and states that "professions are always engaged in a [sic] ongoing process to legitimate themselves."

Lui et al. (2003) provide a different spin to the professional socialisation process. They write that an individual becomes socialised to become well-adjusted to his or her work in his or her profession; that this represents an implicit understanding among professional workers about what constitutes appropriate behaviour at work and which tend to conform to a 'code of ethics' in order to gain social acceptance, out of fear of social reprisal and generally to avoid feeling guilty. The perception that individuals 
conform to a 'code of ethics' 'to gain social acceptance', 'out of fear of social reprisal', and 'to avoid feeling guilty' raises interesting issues as to the type of appropriate behaviour adjustments that are being provided in this professional socialisation process. At the cusp of the legitimacy whirlpool, are these the dilemmas that professional accountants, lawyers and business leaders are presented with when faced with complex and difficult business issues? What guidance would they call upon to decide their behaviour? Does this process determine what individuals need to accept as their 'norm' and 'work culture', if they are to avoid these feelings as a professional and a work colleague? An example that possibly illustrates how individuals can be so unaware of the socialisation process and its dire impact on their behaviour is demonstrated by the words of Enron's former head of investor relations. Mark Koenig, during his trial told jurors: "I wish I knew why I did it. I did it to keep my job, to keep the values that I had in the company, to keep working for the company. I didn't have a good reason." (n.p., quoted in Free et al., 2007).

Fogarty and Dirsmith (2001) explain that organisational socialisation can be viewed from the perspective of institutional theory. They indicate that this theory plays a key role in helping organisations achieve their missions due to the organisational structures or rules of the organisation being established under this theoretical framework. Hensmans (2003), on the other hand, claims that neo-institutional theory gives a richer meaning to the strategy-formation process by integrating issues of ideology, power and agency in a political-cultural rhetoric of legitimation. He argues that power relations provide agencies with the necessary legitimacy to be credible in the first place by mobilising an ideological bias; that is, a set of beliefs that describe, project and indicate a relevant social reality that was derived from already organised interests. This neo-institutional theory approach gives emphasis to a political-cultural rhetoric of legitimation and uses the concept of legitimacy to explain that beliefs are derived from already organised interests. This leads us back to the question of how these beliefs become accepted by individuals. Our discussions on legitimacy theory and its implications for organisational politics and strategies suggests that there is a socialisation process whereby the 'making up' of individuals' values, norms and beliefs are transformed such that individuals are made to 'fit into' the professional and corporate work environment that they see their careers taking off in.

To illustrate this socialisation process and its consequences on society, we will refer to the significant number of finance companies that have failed in New Zealand and discuss how some of the directors of these failed companies seem to have given themselves legitimation without any real personal recourse as to how these companies have actually failed under their leadership and management. Grant (2011, p.62) writes: "[M]any directors take the view that if the business makes a profit they are entitled to the reward and if the business fails then it is the creditors who must shoulder the burden" and that it is often a surprise to directors that they can be held personally responsible for the losses of their companies.

\section{Accountants and directors' roles in the failed New Zealand finance companies}

Since May 2006, a significant number of finance companies ${ }^{1}$ in New Zealand have failed, either being placed into receivership or liquidation, or entering into moratorium 
arrangements with debt holders. Almost four years after the first finance company fell over; Macfie (2010) indicates that this collapse marked the beginning of a $\$ 6$ billion financial meltdown. O'Neill (2011, p.D2) in his investigations of what happens to investor funds under receivership writes that "it makes ugly reading." In 2011, the Parliamentary Commerce Committee (2011) estimated that these failures put at risk over $\$ 6$ billion of investors' deposits, much of which will never be recovered. It was estimated that between 150,000 and 200,000 deposit holders have been affected, and the losses to date have been estimated at over $\$ 3$ billion.

The actual amount is difficult to determine, given how different commentators have quantified the total, see for example the amount stated by Hickey (2014) in the Interest.co.nz 'deep freeze' website (refer Appendix) which identifies 67 companies, comprising \$9.290 billion, affecting 242,000 investors, many of whom are known to have had investments in more than one failed finance company. Such capital losses do not quantify the ongoing losses arrived from interest not paid by the failed companies which can be estimated at approximately $\$ 800$ million per year, with that non-payments being divided between the 'lost' tax not paid to the government (which depending on the amount and marginal tax rate can amount to around $25 \%$ of this lost interest), and the resultant loss of spending opportunity in the wider business community: the non-expenditure on consumer goods, travel, replacement housing, etc. Such 'losses' are generally described as the non-calculated by-product of these corporate collapses. They illustrate the losses borne by investors, not directors. However, it is a positive turn to see that directors are now being held accountable through prosecutions (explained below). But, is it of history repeating itself after the last financial crisis of the 1980s, and, again a case of being too little and too late.

The recurring theme from the failed finance company cases can be broadly summarised as the failure of corporate governance, particularly with respect to the independence of directors, self-interested and related-parties transactions, failure of accountability, compliance and disclosure principles; poor or often non-existent proactive regulatory oversight; an enabling rather than prescriptive corporate regulation; and lastly, a focus on ex post rather than ex ante consideration of principles relating to application of the concept of materiality as considered by directors, accountants auditors and regulators.

Poor corporate governance has been identified as a leading cause of the collapse of many finance companies. In particular, a number of the failed finance companies were dominated by a chief executive or board chairperson who was the main architect of the company's method of operation. The boards tended to lack the breadth of experience and skills required to oversee the scale, complexity and characteristics of financing operations that were undertaken. For too many, there was no independent director, or certainly no majority of independent directors. Too often, directors were not adequately informed, misled or failed to take sufficient interest in the affairs of the company.

Another significant feature is that investors in such finance companies were just that, investors, not shareholders, with all the attendant rights that shareholders might expect. Thus, anecdotal comments about investors not receiving company annual reports or annual financial statements reveals a general misunderstanding of entitlements of investors, and the obligations of such companies to make available company annual reports or annual financial statements. Annual financial statements had to be prepared when prospectuses were registered, and thus provided the regulators one source of documentation upon which to use when bringing charges under the Securities Act, but, as the case analyses establish, many directors, while believing in compliance with 
Securities Act 1986 legislation, either did not understand or consider the actual legislative requirements. One can discern an element of dramaturgical accountability and compliance in their actions.

Examples exist of directors' misleading the public through incorrect statements in prospectuses, or taking advantage of poor or non-existent regulation, or even informed policy and practice in certain accounting areas. The treatment of non-performing loans provides one such area. A number of companies engaged in the practice of rolling-up a non-performing loan into a new loan that included the original principal and the arrears in interest. This resulted in the true performance of the loan portfolio being masked to avoid the classification of these loans as being in default. The disclosure documents of several companies effectively misled investors as to the quality of the company's lending practices and performance because they reported low or nil defaults. High Court Justice Venning commented on such practices in Paragraphs 22-26 of his judgement delivered on 13 March 2013 when sentencing Colin Gregory Ryan, Robert Gordon Sutherland and Owen Francis Tallentire, as directors of Capital + Merchant Finance Ltd. (CMF). ${ }^{2}$

"Management of loans

[22] The 2007 prospectus also represented all loans were actively monitored by CMF's credit committee regularly and that any request by a borrower to roll over or extend their loan was subject to the credit criteria of CMF and was treated to the same level of scrutiny as an original loan application. Those statements were untrue.

Impairment

[23] The 2007 prospectus next represented that no loans were impaired and no provision was required for past due assets. At the time the prospectus was registered there were already a number of loans that were clearly impaired.

\section{No material adverse circumstances}

[24] The 2007 prospectus further represented that no circumstances had arisen that materially adversely affected:

- the profitability of CMF;

- the value of its assets; or

- its ability to pay its liabilities due in the following 12 months.

Those statements were untrue.

[25] The representative advertisement charge refers to a number of documents. First, the 2006 investment statement dated 15 August 2006 which included a number of misleading statements about related party lending, liquidity and cash flow, and loan management, which had the effect of misrepresenting the quality and risk of investments in CMF to members of the public.

[26] The 2007 investment statement dated 10 September 2007 included the same untrue statements which again misrepresented the quality and risk of investments in CMF."

Accountants and auditors unwittingly or possibly even negligently - cases are still to be decided - were complicit or ignorant of such practices. The enabling nature, rather than a prescriptive regime, of corporate finance accountability, compliance and disclosure 
principles permitted certain directors to exploit commercial opportunities for self-interest and related parties, another emergent theme in this analysis.

The financial track record of many company CEOs and directors support the notion of poor governance being a key cause company failure. Some CEOs and company directors were associated with previous company failures within the financial sector. Bridgecorp founder Rod Petricevic was involved in the $\$ 250$ million failure of Euro National in the late 1980s; Roger (Kenneth) Moses of Nathans Finance NZ Limited was involved in the failed contributory mortgage broking firm Reeves Moses Hudig. Michael Reeves of Lombard Finance and Investments Limited had pleaded guilty in 2006 to a breach of the Securities Act 1978 relating to an earlier failure of a contributory mortgage scheme. The fact that these individuals were allowed to continue operating, be it under a different company name, is considered indicative of the passive and ineffective nature of the financial regulation and legislative environment surrounding the wider industry.

The eventual prosecutions by the Financial Markets Authority (FMA) of many directors of failed finance companies, has enabled the identification and application of principles pertaining to corporate standards. In these cases over the last 12 months, the courts' focus and case utility has been on sentencing principles for directors for their often-cavalier attitude and disregard of established principles of accountability, compliance and disclosure, thus giving rise to the themes that have flowed throughout the many decisions forming the basis of this analysis.

Moreover, general principles have emerged relating to expected standards for boards and directors. For example, on May 2013, the Court of Appeal released its decision in respect of the Lombard directors' appeal ${ }^{3}$ against their convictions and crown's appeal against sentence. The court reaffirmed in Para. 82 the message in R v Steigrad (2011) NZCA 304 that the purpose of the Securities Act 1986 is to protect the investing public through timely disclosure of material information. The court further reaffirmed the principle that the duty in Section 58 of the Securities Act is non-delegable, and in this case the directors could not reasonably have relied on the advice of management or their professional advisers. Ultimately, the responsibility to govern and manage the company lies with the directors (Para. 196).

The decision also contains useful guidance on the defences to be applied and the interaction of directors' duties under the Securities Act and under the Companies Act 1993. On this point, the Court of Appeal specifically noted (in Para. 172) that when a public offer is made, the statutory obligation is to ensure that offer documents are true, and that obligation overrides the duty that directors owe to the company to act in its best interests (where those duties may conflict). If directors cannot be satisfied that the statements in offer documents are true and not misleading by omission, then the offer should not be made, or have been made, irrespective of the consequences that might then flow.

In granting the crown's application for leave to appeal against sentence, the court held that the trial judge did not give enough weight to the sentencing purposes of denunciation and general deterrence, and of holding offenders accountable. The court also held that the trial judge failed to give sufficient weight to the purpose of the Securities Act, being to protect the investing public through timely disclosure of material information. The Court of Appeal observed (in Para. 249): 


\begin{abstract}
"The investing public is highly dependent upon the truthful disclosure of relevant information in offer documents. This is required to facilitate the raising of capital and to promote confidence by the investing public in financial markets. Failure to meet the required standards has a number of potential consequences: loss of investor confidence, lack of trust in this country's financial institutions, damage to capital markets and the wider economy; and loss of funds invested by the public."
\end{abstract}

This section of the paper thus sets out the general background to the finance company collapse which rushed, tsunami-like, through the New Zealand corporate investment world 2006-2010, with the subsequent rebuilding of commercial and legal confidence being based on judicial principles, sentencing guidelines and renewed regulatory activism - by the now-established regulator, the FMA. The specific messages from the decisions of the courts provide further guidance for directors concerning their responsibilities under securities legislation, to ensure the ongoing relevance, accuracy and adequacy of offer documents for the benefit of investors.

Being a director is more than just a title. Regardless of the exact role or title, as a director of a public issuer, executive or non-executive, de facto director, the courts have continued to hold that directors have a responsibility to investors to make full and accurate disclosures, and to ask questions and make enquiries if they do not understand clearly the business of the company. The message is clear; all directors will be held accountable if they do not (FMA, 2013).

By the end of 2013, 32 directors of failed finance companies have been convicted as a result of prosecutions pursued by FMA. Court decisions in this year have focused on sentencing principles, giving rise to various identifiable factors, including:

- The individual level of culpability: From errors of judgement and abdication of responsibility at one end, to negligence, gross negligence, and dishonesty and concealment at the other.

- The nature of the director's role: Those more closely involved are more responsible.

- Guilty pleas and cooperation have led to marginally discounted sentences.

- $\quad$ Remorse and reparation have led to marginally discounted sentences.

- Previous good character and family circumstance have also led to marginally reduced sentences.

This section of the paper, therefore, identified principles arising from the convictions of various company directors responsible for numerous finance companies collapse in the period 2006-2010. These principles provided guidance and lessons about issues of poor governance, related-party transactions, non-consideration of matters of 'materiality', and an insufficient even non-existent regulatory oversight and environment. The focus is on statements of principles was gleaned from the many, often lengthy court decisions. These cases represent the result of prosecutions by both the Serious Fraud Office (SFO) and FMA for breaches of New Zealand's Securities Act 1986 and the Companies Act 1993. Such convictions reveal the extent to which breaches occurred set against a background of corporate opportunity, disdain for accepted corporate mores, a belief by certain directors in that what they were doing was lawful, and that, in that, the free market encouraged and rewarded corporate entrepreneurship and initiatives, that is, the legitimisation of their actions. Will lessons be learnt from these prosecutions about 
directors needing to have responsible and ethical behaviour in their decision making? Or will there be a case of déjà vu - history will be repeated after the dust settles from these current prosecutions?

\section{Summary and conclusions}

This paper explained the concept of legitimacy and examined legitimacy theory in terms of its positioning in accounting and business research literature and its applicability in explaining the actions and behaviour of accounting and corporate professionals. Legitimacy theory focuses on the values that society holds true and the notion that organisations survive only because they recognise that there is a social contract between them and society. The issues discussed in this paper should provide an important backdrop to our attempts in trying to understand, why in spite of research literature that indicates significant development and advances in not just ethics education but in business/management education, generally as well as changes in law and accounting standards, that there does not appear to have been much impact in halting accounting scandals and corporate debacles. The discussion in this paper highlights that, perhaps accounting/business education researchers need to look more carefully at the concept of legitimacy and legitimacy theory, in order to better understand the behaviour of accounting and business professionals, the corporate/enterprise culture that major businesses promote, and the types of legitimation strategies that they develop to legitimate their social contract with society.

The issues raised in this paper therefore suggest that there is a legitimacy whirlpool that accounting and business graduates need to be aware of and to develop resilience against when commencing their professional careers. Educators and researchers need to therefore pay more careful attention to the types of ethical challenges that will confront graduates once they leave university and become the next generation of accounting and business professionals. These individuals will require guidance and preparation in their educational programs that must include appropriate ethical educational interventions to withstand temptations identified in the legitimacy whirlpool. Inappropriate legitimation type strategies that might be imposed upon them when they commence their professional careers will ultimately in the longer term not only adversely affect them directly in a personal way but can also bring disrepute to the professional bodies to which they belong. These individuals must continually confront and challenge themselves when faced with such ethical dilemmas. The fundamental question that they need to ask of themselves when faced with a decision that can have dire consequences for the wider society even though they can stand to gain for themselves, significant personal wealth and success is: strategy or character ... if you have to be without one, which should it be? It is, therefore, imperative that Free et al.'s (2007) words are heeded, that the most important lesson for managers to take away from the Enron saga was not to abandon professional integrity; that they had to find a working environment that matches their own personal values and principles and if it did not match, they should leave and find a company that does. 


\section{References}

AACSB International (2004) Ethics Education in Business Schools, Report of the Ethics Task Force to AACSB International Board of Directors, No. MO 63141, AACSB International, The Association to Advance Collegiate Schools of Business, St Louis.

Alam, M. (Ed.) (2006) 'Stakeholder theory', in Hoque, Z. (Ed.): Methodological Issues in Accounting Research: Theories and Methods, Spiramus Press Ltd., London.

Anderson-Gough, F., Grey, C. and Robson, K. (1998) Making Up Accountants: The Organizational and Professional Socialization of Trainee Chartered Accountants, Ashgate Publishing Ltd., England.

Bauman, Z. (1989) Modernity and the Holocaust, Polity Press, UK.

Bloom, R., Heymann, H.G., Fuglister, J. and Collins, M. (1994) The Schism in Accounting, Quorum Books, London.

Boatright, J. (2000) Ethics and the Conduct of Business, Prentice Hall, New Jersey.

Brinkerhoff, D.W. and Brink, D. (2005) 'Organisational legitimacy, capacity and capacity development', Paper presented at the Public Management Research Association, 8th Research Conference, School of Policy, Planning and Development, University of Southern California, 20 September-1 October.

Brown, A.D. (1997) 'Narcissism, identity, and legitimacy', The Academy of Management Review, July, Vol. 22, No. 3, pp.643-686.

Bryce, R. (2003) Pipe Dreams: Greed, Ego and the Death of Enron, Public Affairs, New York.

Brymer, G. (2005) Vital Integrities: How Values-based Leaders Acquire and Preserve Their Credibility, All Square, Inc.

Butcher, D. and Clarke, M. (1999) 'Organisational politics: the missing discipline of management?', Industrial and Commercial Training, Vol. 31, No. 1, p.9.

Cavanagh, G.F., Moberg, D.J. and Velasquez, M. (1981) 'The ethics of organizational politics', The Academy of Management Review, July, Vol. 6, No. 3, pp.363-374.

Clark, K. and Lavelle, M. (2006) 'Guilty as charged! A verdict on Enron's top two executives... and on an entire era', U.S. News and World Report, 5 June, Vol. 140, No. 21, pp.44-45, Washington.

Clay-Warner, J. (2006) 'Procedural justice and legitimacy: predicting negative emotional reactions to workplace injustice', in Thye, S.R. and Lawler, E.J. (Ed.): Advances in Group Processes (Advances in Group Processes, Vol. 23), Emerald Group Publishing Limited, Bingley, pp.207-227.

Commerce Committee (2011) Inquiry into Finance Company Failures (I.1A), 11 October [online] http://www.parliament.nz/ennz/pb/sc/documents/reports/49DBSCH_SCR5335_1/inquiry-intofinance-company-failures-i1a (accessed 5 February 2014).

Craig, R. and Amernic, J.H. (2002) 'Accountability of accounting educators and the rhythm of the university: resistance strategies for postmodern blues', Accounting Education: An International Journal, Vol. 11, No. 2, pp.121-171.

Craig, R. and Amernic, J.H. (2004) 'Enron discourse: the rhetoric of a resilient capitalism', Critical Perspectives on Accounting, Vol. 15, Nos. 6-7, pp.813-851.

De George, R.T. (1995) Business Ethics, 4th ed., Prentice Hall, Inc., New Jersey.

Deegan, C. (2002) 'The legitimising effect of social and environmental disclosures - a theoretical foundation', Accounting, Auditing and Accountability Journal, Vol. 15, No. 3, pp.282-311.

Deegan, C. (Ed.) (2006) 'Legitimacy theory', in Hoque, Z. (Ed.): Methodological Issues in Accounting Research: Theories and Methods, Spiramus Press Ltd., London.

Deegan, C. and Rankin, M. (1997) 'The materiality of environmental information to users of annual reports', Accounting, Auditing and Accountability Journal, Vol. 10, No. 4, pp.562-583.

Donker, H., Poff, D. and Zahir, S. (2008) 'Corporate values, code of ethics, and firm performance: a look at the Canadian context', Journal of Business Ethics, Vol. 82, No. 3, pp.527-537. 
Dornbusch, S.M. and Scott, W.R. (1975) Evaluation and the Exercises of Authority, Jossey-Bass, San Francisco.

Eppler, M. (2005) Management Mess-ups: 57 Pitfalls You Can Avoid (And Stories of Those Who Didn't), Career Press, USA.

FMA (2013) Financial Markets Conducts Act 2013 [online] https://www.fma.govt.nz/aboutus/how-we-regulate/legislation/ (accessed 18 October 2020).

Fogarty, T.J. and Dirsmith, M.W. (2001) 'Organizational socialization as instrument and symbol: an extended institutional theory perspective', Human Resource Development Quarterly, Fall, Vol. 12, No. 3, pp.247-266.

Free, C., Macintosh, N. and Stein, M. (2007) 'Management controls: the organizational fraud triangle of leadership, culture and control in Enron', IVEY Business Journal, July/August [online] http://www.iveybusinessjournal.com/article.asp?intArticle_ID=701 (accessed 9 April 2010).

Grant, D. (2011) 'Directors held to account for a reason', Herald on Sunday, 30 January, p.62.

Gray, B. and Ariss, S.S. (1985) 'Politics and strategic change across organizational life cycles', The Academy of Management Review, October, Vol. 10, No. 4, pp.707-723.

Gray, R., Owen, D. and Adams, C. (1996) Accounting and Accountability: Changes and Challenges in Corporate and Social Reporting, Prentice Hall, London.

Grey, C. (2003) 'The real world of Enron's auditors', Organization, Vol. 10, No. 3, pp.572-576.

Guthrie, J. and Parker, L.D. (1990) 'Corporate social disclosure practice: a comparative international analysis', Advances in Public Interest Accounting, Vol. 3, pp.159-176.

Hegtvedt, K.A. and Johnson, C. (2000) 'Justice beyond the individual: a future with legitimation', Social Psychology Quarterly, Vol. 63, No. 4, pp.298-311.

Hensmans, M. (2003) 'Social movement organizations: a metaphor for strategic actors in institutional fields', Organization Studies, Vol. 24, No. 3, pp.355-381.

Herrick, D.F. (2003) Media Management in the Age of Giants: Business Dynamics of Journalism, Iowa State Press/Blackwell Publishing.

Hickey, B. (2014) Deep Freeze List [online] https://www.interest.co.nz/saving/deep-freeze-list (accessed 5 February 2014).

Hooghiemstra, R. (2000) 'Corporate communication and impression management - new perspectives why companies engage in corporate social reporting', Journal of Business Ethics, Vol. 27, pp.55-68.

interest.co.nz (n.d.) Deep Freeze List - Finance Industry Failures [online] https://www.interest.co.nz/saving/deep-freeze-list (accessed 20 October 2019).

International Federation of Accountants (IFAC) (2006) Approaches to the Development and Maintenance of Professional Values, Ethics and Attitudes in Accounting Education Programs, Information Paper, August, International Federation of Accountants, New York.

Jensen, M.C. and Meckling, W.H. (1994) 'The nature of man', Journal of Applied Corporate Finance, Vol. 7, No. 2, pp.4-19.

Jing, F.F. and Avery, G.C. (2008) 'Missing links in understanding the relationship between leadership and organizational performance', International Business \& Economics Research Journal, May, Vol. 7, No. 5, pp.67-78.

Johnston, D.C. (2002) 'Big accounting firm's tax plans help the wealthy conceal income', The New York Times [online] http://query.nytimes.com (accessed 3 December 2008).

Lachs, J. (1981) Responsibility of the Individual in Modern Society, Harvester Press, Brighton, Sussex.

Larson, V. (2010) 'Heroes and zeroes', North \& South, May, p.10.

Leung, P. and Cooper, B.J. (2005) 'Accountants, ethical issues and the corporate governance context', Australian Accountant Review, Vol. 15, No. 1, pp.79-88. 
Lewis, R. and Meng-Yee, C. (2010) ‘\$405k for Hotchin to get away from it all’, Herald on Sunday, 16 May, p.7.

Lindblom, C.K. (1993) 'The implications of organizational legitimacy for corporate social performance and disclosure', Paper presented at the 1993 Critical Perspectives on Accounting Conference.

Low, M., Davey, H. and Hooper, K. (2008) 'Accounting scandals, ethical dilemmas and educational challenges', Critical Perspectives on Accounting, Vol. 19, No. 2, pp.222-254.

Lui, S.S., Ngo, H. and Tsang, A.W. (2003) 'Socialized to be a professional: a study of the professionalism of accountants in Hong Kong', The International Journal of Human Resource Management, Vol. 14, No. 7, pp.1192-1205.

Macfie, R. (2010) 'You are in safe hands', New Zealand Listener, 10 April, Vol. 223 , No. 3648, pp..-6-23.

Magness, V. (2006) 'Strategic posture, financial performance and environmental disclosure: a test of legitimacy theory', Accounting, Auditing and Accountability Journal, Vol. 19, No. 4, pp.540-563.

Mansell, I. (2004) 'Revenue widens inquiry into accounting firms', The Times [online] http://business.timesonline.co.uk (accessed 3 December 2008).

Marshall, J. (2008) 'Investors angry as Hanover Boss parties', Sunday Star Times, 30 November, p.3.

Marshall, J. (2010a) ‘Inside Hotchin's Hawaiian hideaway’, Sunday Star Times, 16 May, p.A1.

Marshall, J. (2010b) 'Work stops on Hotchin mansion', Sunday Star Times, 9 May, p.A2.

McDonald, G. (2007) 'Business ethics and the evolution of corporate responsibility', Chartered Accountants Journal, March, Vol. 86, No. 2, pp.12-14.

McDonald, S. (2009) 'Eric Watson ups the stakes with exclusive Istanbul party', The National Business Review, 8 April.

McNabb, D. (2008) 'Petricevic spent while Bridgecorp burned', Stuff - IFR - Business, 5 June, pp.1-3.

McPhail, K. (2003) 'Relocating accounting and business ethics: reflections on a business ethics retreat in Scotland's National Park', The British Accounting Review, Vol. 35, No. 4, pp.349-366.

Misa, T. (2007) 'The price of remorse: \$10,000 v \$168.40', Weekend Herald, 2 June, p.A1.

Narayan, V.K. and Fahey, L. (1982) 'The micro-politics of strategy formulation', The Academy of Management Review, July, Vol. 7, No. 1, pp.25-34.

National Commission on Fraudulent Financial Reporting (1987) Report of the National Commission on Fraudulent Financial Reporting,, October [online] https://www.coso.org/ Documents/NCFFR.pdf (accessed 18 October 2020).

Ninness, G. (2008) 'Bryers \$30m properties revealed', Sunday Star Times, 21 September, Edition A, p.1.

O’Neill, R. (2011) 'Investors still see red over Hotchin and Co.', Sunday Star Times, 20 February, p.D2.

Patten, D.M. (1991) 'Exposure, legitimacy, and social disclosure', Journal of Accounting and Public Policy, Vol. 10, No. 4, pp.297-308.

Patten, D.M. (1992) 'Intra-industry environmental disclosures in response to the Alaskan oil spill: a note on legitimacy theory', Accounting, Organizations and Society, Vol. 17, No. 5, pp.471-475.

Pava, M.L. and Krausz, J. (1997) 'Criteria for evaluating the legitimacy of corporate social responsibility', Journal of Business Ethics, Vol. 16, No. 3, pp.337-347.

Perelman, M. (2005) Manufacturing Discontent: The Trap of Individualism in Corporate Society, Pluto Press, London. 
Phillips, R. (2003) Stakeholder Theory and Organizational Ethics, Berrett-Koehler Publishers, Inc., San Francisco.

Preuss, L. (1998) 'On ethical theory in auditing', Managerial Auditing Journal, Vol. 13, No. 9, pp.500-508.

Ratanajongkol, S., Davey, H. and Low, M. (2006) 'Corporate social reporting in Thailand: the news is all good and increasing', Qualitative Research in Accounting and Management, Vol. 3, No. 1, pp.67-83.

Richardson, A.J. and Dowling, J.B. (1986) 'An integrative theory of organizational legitimation', Scandinavian Journal of Management Studies, November, pp.91-109.

Ruef, M. and Scott, W.R. (1998) 'A multidimensional model of organizational legitimacy: hospital survival in changing institutional environments', Administrative Science Quarterly, December, Vol. 43, No. 4, pp.877-904.

Safferstone, M.J. (2005) 'Organizational leadership: classic works and contemporary perspectives', CHOICE: Current Reviews for Academic Libraries, Vol. 42, No. 6, pp.959-975.

Sennett, R. (1998) The Corrosion of Character: The Personal Consequences of Work in the New Capitalism, W.W. Norton and Company, New York, London.

Shocker, A.D. and Sethi, S.P. (Eds.) (1974) 'An approach to incorporating social preferences in developing corporate action strategies', in Sethi, S.P. (Ed.): The Unstable Ground: Corporate Social Policy in a Dynamic Society, Melville Publishing Company, Los Angeles.

Sikka, P. (2007) 'Enterprise culture and accountancy firms: new masters of the universe', Accounting, Auditing and Accountability Journal, Vol. 21, No. 2, pp.268-295.

Sims, R. (2002) Teaching Business Ethics for Effective Learning, Quorum Books, Westport, CT.

Solomon, J. (2007) Corporate Governance and Accountability, 2nd ed., John Wiley and Sons Ltd., West Sussex, England.

Spence, C., Husillos, J. and Correa-Ruiz, C. (2010) 'Cargo cult science and the death of politics: a critical review of social and environmental accounting research', Critical Perspectives on Accounting, Vol. 21, No. 1, pp.76-89.

Stickley, T. and Yandall, P. (2001) 'Borrowers fight to keep homes', Weekend Herald, 13-14 January, p.A2.

Suchman, M.C. (1995) 'Managing legitimacy: strategic and institutional approaches', The Academy of Management Review, Vol. 20, No. 3, pp.571-610.

Sundem, G. (1990) The Accounting Education Change Commission: Its History and Impact. Accounting Education Series, Vol. 15, American Accounting Association, Sarasota.

Trevett, C. and NZPA (2007) 'Cut-off death is a disgrace: Clark', Weekend Herald, 2 June, p.A3.

Underwood, J. (2004) What's Your Corporate IQ?: How the Smartest Companies Learn, Transform, Lead, Dearborn Trade, a Kaplan Professional Company, Chicago, IL, USA.

Walker, H.A. and Zelditch, M. (1993) 'Power, legitimacy, and the stability of authority: a theoretical research program', in Berger, J. and Zelditch, M. (Eds.): Theoretical Research Programs: Studies in the Growth of Theory, pp.364-381, Stanford University Press, Stanford, CA.

Warren, R.C. (2003) 'The evolution of business legitimacy', European Business Review, Vol. 15, No. 3, pp.153-163.

Weber, M. (1947) The Theory of Social and Economic Organization, trans. By Henderson, A.M. and Parsons, T., Free Press, New York.

Weber, M. (1968) Economy and Society, in Roth, G. and Wittich, C. (Eds.), translated by Fischoff, E., Hans, G., Henderson, A.M., Ferdinand, K., Wright, C.M., Parsons, T., Rheinstein, M., Roth, G., Shils, E. and Claus, W., Bedminster Press, New York.

Weidman, J.C., Twale, D.J. and Stein, E.L. (2001) Socialization of Graduate and Professional Students in Higher Education: A Perilous Passage? ASHE-ERIC Higher Education Report, Vol. 28, No. 3, Jossey-Bass, San Francisco. 
Williams, P.F. (2002) 'Accounting and the moral order: justice, accounting, and legitimate moral authority', Accounting and the Public Interest, Vol. 2, No. 1, pp.1-21.

Wilmshurst, T.D. and Frost, G.R. (2000) 'Corporate environmental reporting: a test of legitimacy theory', Accounting, Auditing and Accountability Journal, Vol. 13, No. 1, pp.10-26.

Yeager, P.C. (1995) 'Management, morality, and law: organizational forms and ethical deliberations', in Pearce, F. and Snider, L. (Eds.): Corporate Crime: Contemporary Debates, pp.147-167, University of Toronto Press, Toronto.

Young, S. (2003) Moral Capitalism: Reconciling Private Interest with the Public Good, Berrett-Koehler Publishers, San Francisco.

Zahra, S.A. (1987) 'Organizational politics and the strategic process', Journal of Business Ethics, October, Vol. 6, pp.579-587.

Zelditch, M. (2001) 'Process of legitimation: recent developments and new directions', Social Psychology Quarterly, Vol. 64, No. 1, pp.4-17.

Zelditch, M. (Ed.) (2006) 'Legitimacy theory', in Burke, P. (Ed.): Contemporary Social Psychological Theories, Stanford University Press, California.

Zelditch, M. and Walker, H.A. (1984) The Legitimacy of Regimes, Power and Status Advances in Group Processes, Vol. 20, pp.217-249.

\section{Notes}

1 Interest.co.nz states 67 companies as at 17 February 2014, the Commerce Commission in 2011 identified 45 as at December 2010. Refer Appendix.

2 RV RYAN \& ORS HC AK CRI-2009-004-028345 (15 March 2013).

3 Jeffries et al. v R CA (2013) NZCA 188 (full names of parties: William Patrick Jeffries, Michael Howard Reeves, Douglas Arthur Montros Graham and Lawrence Roland Valpy Bryant) Decision of Randerson J. The defendants have notified their intention to seek leave to appeal to the Supreme Court. Supreme Court appeal heard on February 2014, but as at date of writing, no decision has been announced. 


\section{Appendix}

Deep freeze list - finance industry failures

This page is a list of the finance industry failures since 2006. Posted in Saving (http://www.interest.co.nz/saving/deep-freeze-list).

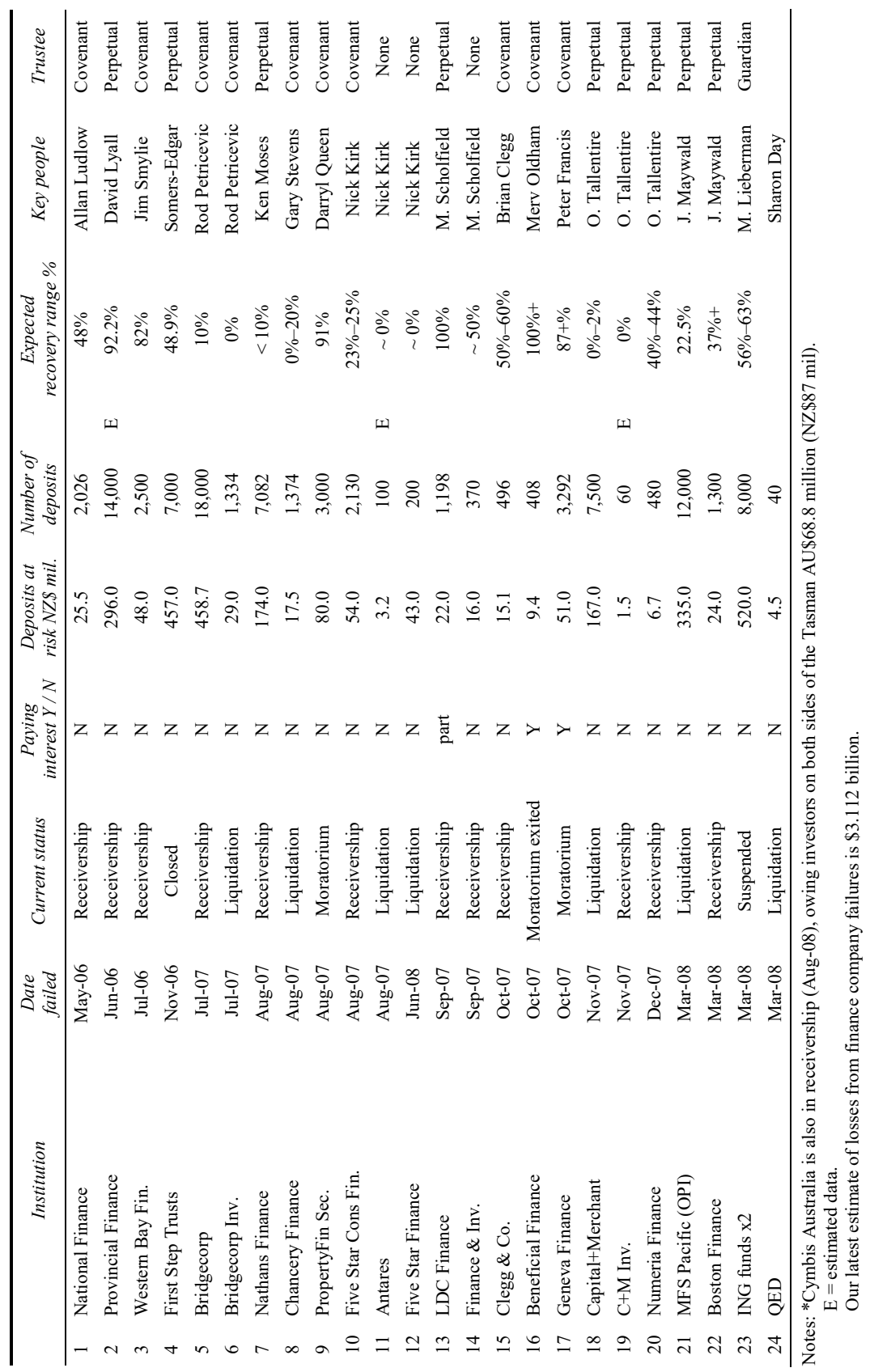


Deep freeze list - finance industry failures (continued)

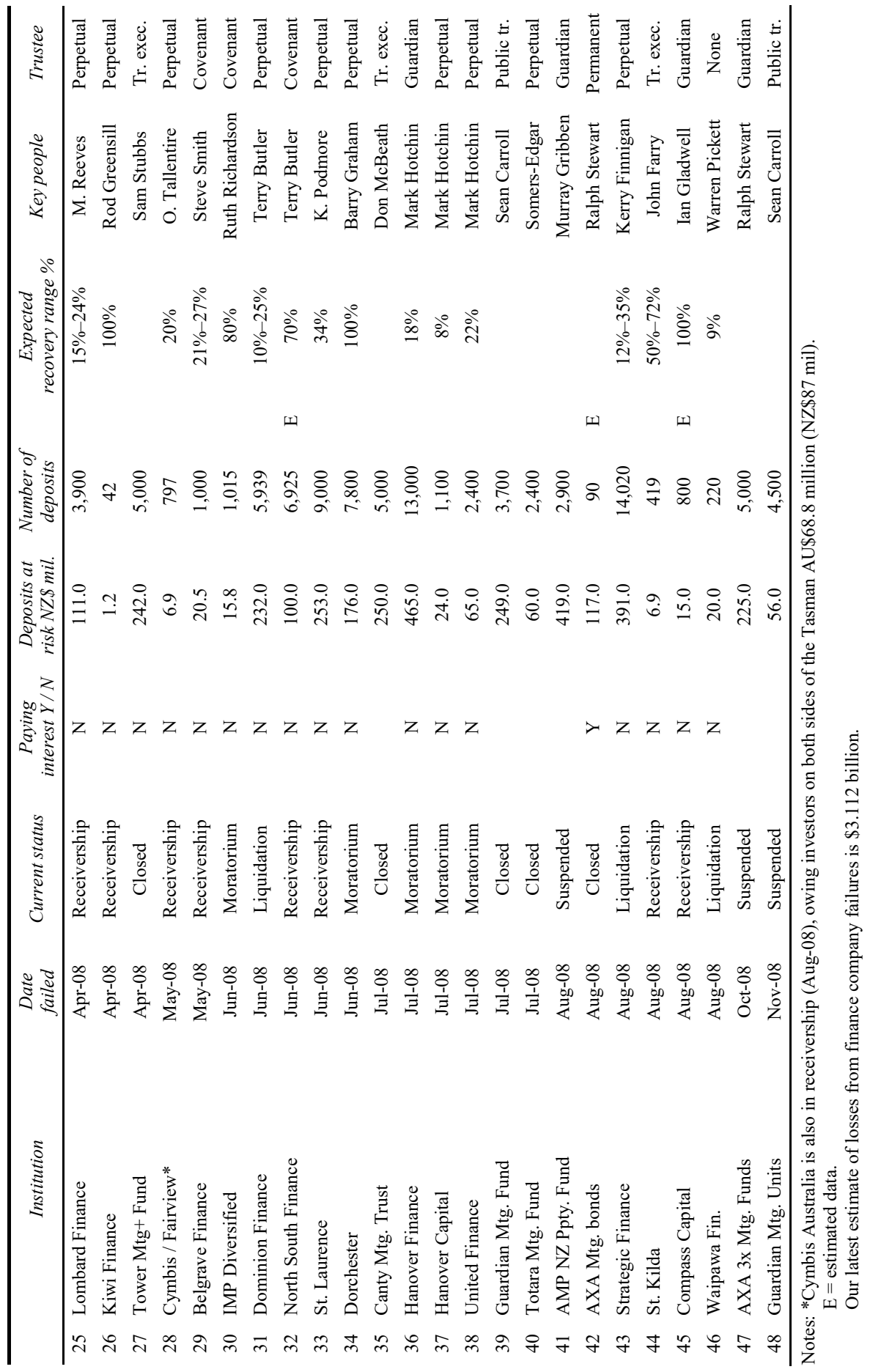


Deep freeze list - finance industry failures (continued)

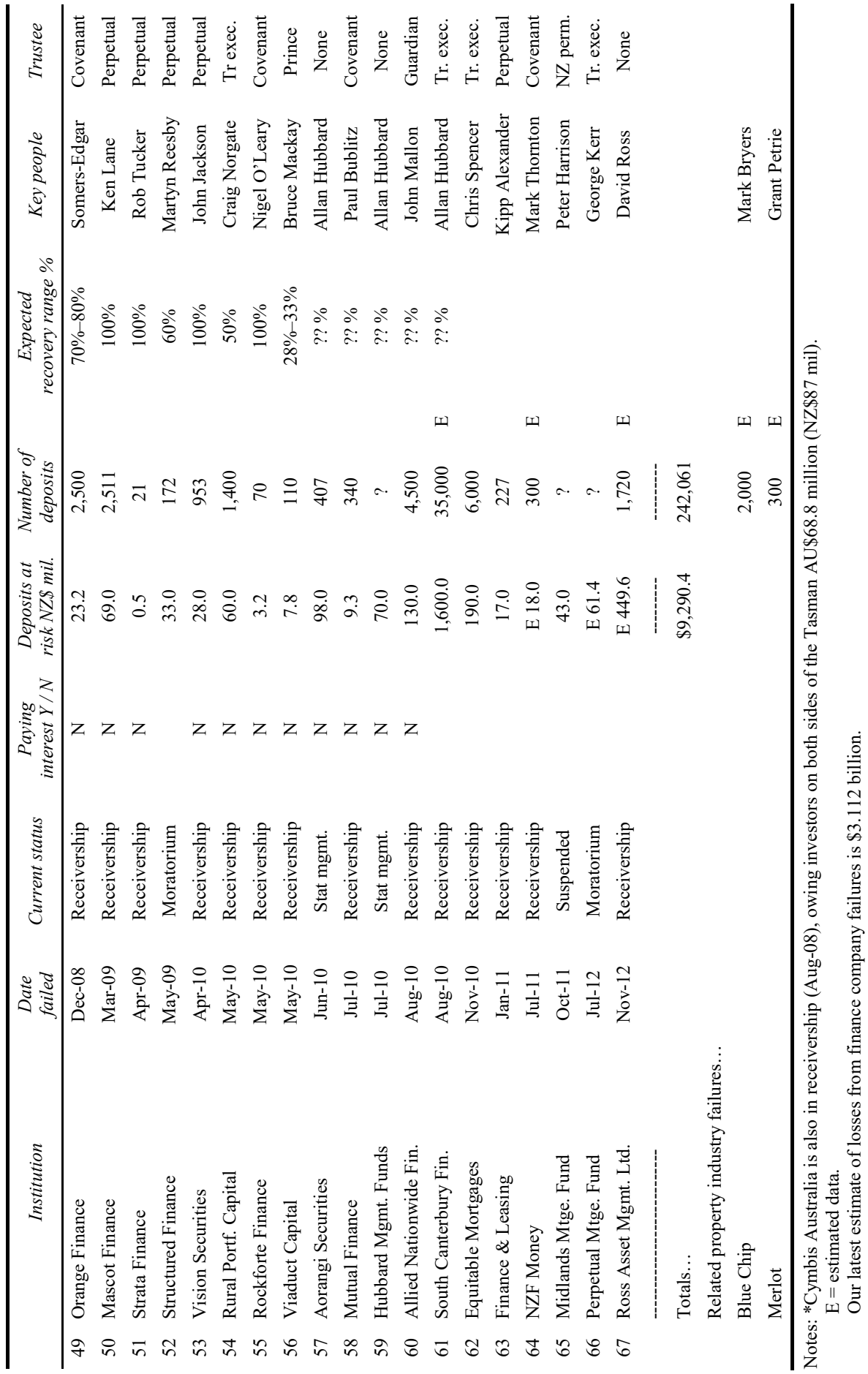

